\title{
Institutional Factors and Conditional Conservatism in Malaysia: Does International Financial Reporting Standards Convergence Matter?
}

\author{
Marziana Madah Marzuki \\ Faculty of Accountancy \\ Universiti Teknologi Mara \\ Bukit Ilmu \\ 18500 Machang, Kelantan \\ Malaysia \\ marziana@kelantan.uitm.edu.my \\ Effiezal Aswadi Abdul Wahab ${ }^{\#}$ \\ School of Accounting \\ Curtin Business School \\ Curtin University of Technology \\ Bentley, Perth 6102 \\ Western Australia \\ effiezal.abdulwahab@curtin.edu.au
}

\section{${ }^{\#}$ Corresponding author}

We thank Professor Heibatollah Sami for comments and Professor Katherine Schipper for valuable discussions on earnings conservatism. We extend our gratitude to participants at the Journal of Contemporary Accounting and Economics (JCAE) 2014 Symposium for valuable insights. This work was supported by Curtin University through its Curtin Business School Journal Publication Support. 


\title{
Institutional Factors and Conditional Conservatism in Malaysia: Does International Financial Reporting Standards Convergence Matter?
}

\begin{abstract}
We examine the impact of International Financial Reporting Standards (IFRS) convergence on conditional conservatism in Malaysia. In addition, we examine the influence of various institutional factors, namely, political connections, Bumiputras directors, family firms and richest-men connections on conservatism. Prior literature presents evidence of IFRS convergence on conservatism, but limited evidence exists on the role of institutional factors on conservatism. Using a sample of 1760 firm-year observations from 2004 to 2008, we provide evidence that IFRS enhances conservatism. Firms with Bumiputras directors and family firms are more conservative post-IFRS convergence, whereas the reverse behaviour results for firms with richestmen connections. We find no evidence of politically connected firms being more conservative post-IFRS convergence. Our study provides knowledge on the role of IFRS in conditional conservatism and the role of institutional factors in this relationship.
\end{abstract}

JEL classification: M41, M48, G34, G38

Keywords: Earnings Conservatism, Malaysia, International Financial Reporting Standards 


\section{Introduction}

Although some studies investigate the relationship between International Financial Reporting Standards (IFRS) and conditional conservatism, few attempt to investigate the impact of IFRS on conditional conservatism in Malaysia, where IFRS convergence was adopted in 2006. ${ }^{1}$ This presents as our first research objective.

Previous research on IFRS documents that not all studies achieve similar results. Differences in financial reporting quality are attributable to differences in institutional settings, such as legal systems (Ball et al., 2003; Bushman \& Piotroski, 2006), enforcement of corporate governance (Ahmed \& Duellman, 2007; Chi et al., 2009; Lara et al., 2009) and the quality of financial reporting that is demanded by government (Pinnuck \& Potter, 2009). Brown (2011) concludes that the extent of IFRS benefits achieved in one country depends on four factors: the nature of the standard used before the change was made to IFRS, the credibility of IFRS compliance, legal or other regulatory backing for the standards and the degree of compliance and monitoring. Ball et al. (2003) and Lara et al. (2008) document that high accounting standards do not guarantee high-quality financial reporting practices and may fail to improve the relevance and reliability of accounting information if enforcement and investor protection are low. Next, the level of enforcement is influenced significantly by the country's legal origin, namely, code or common law. A code-law country is said to have lower levels of enforcement because of the influence of institutional characteristics such as family and political connections (Black \& White, 2003; Gassen et al., 2006; Joos \& Lang, 1994; Lara \& Mora, 2004). Malaysia presents an interesting case because the

\footnotetext{
${ }^{1}$ We use accounting conservatism, conditional conservatism, asymmetric timeliness and earnings conservatism interchangeably throughout this paper.
} 
country has adopted accounting standards from common-law countries, such as the USA and the UK, that are considered to have high standards of financial reporting. However, Malaysia's institutional characteristics are similar to those of code-law countries such as Germany and Japan, where the main sources of finance are from a system of relationship-oriented capital rather than dispersed shareholders, and where there is an ability to smooth earnings to report a lower income and therefore attract lower tax (Ball et al., 2000; Ball et al., 2003).

Literature suggests that the implementation of IFRS alone is insufficient to explain the impact on conditional conservatism, and that those institutional factors that are embedded deeply in a country's institutional settings must be considered. Andre et al. (2015) examine the effect of mandatory IFRS adoption on conditional conservatism in Europe, and include a number of institutional factors that complicate the effect of IFRS. They consider two of these to be the quality of the auditing environment and the enforcement of compliance with accounting standards, and find that the decline in conditional conservatism is less pronounced in countries with a high-quality auditing environment and a strong enforcement of accounting standards. We adopt a similar approach by incorporating four local institutional factors that may help to explain the role of IFRS on earnings conservatism. Unlike Andre et al. (2015), we choose factors that are deeply rooted in the Malaysian capital market: political connections, ethnicity, family connections and 'richest-men' connections. We analyse whether these factors affect conditional conservatism in Malaysia, and the impact of IFRS: whether convergence improves or weakens the relationship between institutional factors and earnings conservatism. 
Our first institutional variable is political connections, which is an important determinant for Malaysia's capital market. Literature suggests that politically connected firms in Malaysia are inefficient (Johnson \& Mitton, 2003), risky (Gul, 2006), low in transparency in accounting information (Bushman et al., 2004) and weak in governance (Abdul Wahab et al., 2007). We predict that politically connected firms will be less conservative, because shareholders and stakeholders are less concerned with default risk and encourage these firms to offer non-conservative earnings (Baloria, 2014). Alternatively, politically connected firms could adopt conservative earnings to protect politicians from voter scrutiny (Bushman \& Piotroski, 2006). Because of the ambiguity, we predict, in the null form, that no relationship exists between political connections and conditional conservatism, even post-IFRS. We find no support as to whether politically connected firms are less conservative and whether any relationship exists between connected firms and conservatism post-IFRS convergence.

The second institutional variable is ethnicity, which we define as the proportion of Bumiputras board directors. ${ }^{2}$ Abdul Wahab et al. (2015), Gul (2006) and Johl et al. (2012) use this measure as another proxy for political connections. Johl et al. (2012) argue that firms dominated by Bumiputras directors demonstrate similar characteristics as politically connected firms; they are risk-takers and are inefficient. We find that Bumiputras directors are more conservative after IFRS convergence in 2006, and robust for both measures of conditional conservatism.

Our third institutional variable is family connections. Many Malaysian firms are family-owned (Claessens et al., 2000). Family firms are efficient, and they are expected

\footnotetext{
${ }^{2}$ In Article 153 of the Federal Constitution of Malaysia, Bumiputras are variously defined as 'Malay' and aborigine', 'natives' of Sarawak and 'natives' of Sabah.
} 
to be sustainable into the future. However, they are also subject to nepotism and cronyism, and will have weak expansion plans. Wang et al. (2006) argue that fewer differences exist in information asymmetry in family firms than in non-family firms. Chen et al. (2014) argue that family firms, ex-ante, are more conservative because of their high agency and litigation costs. We find in this study that family firms are more conservative after the convergence of IFRS in 2006 only when we operationalise the family firms based on ownership structure.

The fourth institutional variable is 'richest-man' connections. We offer two arguments in this regard, which are based on the nature of wealth gathering. If the government supports the richest men, then firms owned by these individuals are subject to scrutiny and are weak in governance. In contrast, if the richest men gained their wealth independently, their firms will reflect good governance and the ability to seek external funding. The relationship between richest men and earnings conservatism is therefore rather ambiguous. We find that firms with richest men as the main shareholders are less conservative post-IFRS convergence, and are robust for both measures of conservatism.

Following prior literature (Basu, 1997; Ball \& Shivakumar, 2005; Khan \& Watts, 2009; Lee et al., 2015), we use two different models to estimate firm-year conditional conservatism: (1) the Basu (1997) standard regression and (2) the accrualbased loss recognition model. Based on 440 firms during the pre- (2004-2005) and post- (2007-2008) IFRS periods (1760 firm-year observations), we find that IFRS convergence enhances conditional conservatism, and is robust for both measures.

Our study contributes to accounting research in several ways. We extend literature on the role of IFRS on earnings conservatism. Secondly, we incorporate 
several variables that represent Malaysia uniquely and we provide a fresh understanding of the effect of these factors on earnings conservatism. Our choice of variables is related closely to the argument that Malaysia is a relationship-based economy (Johnson \& Mitton, 2003). We extend relatively scarce research on earnings conservatism and IFRS in Malaysia. To our knowledge, this is the first study that examines the role of IFRS and institutional factors on conservatism simultaneously. To our knowledge, only two published studies exist in this area, that by Mohammad Yunos et al. (2012), which examines the role of culture on conservatism, and that by Wan Ismail et al. (2013), which examines the impact of IFRS on earnings quality in Malaysia.

The remainder of this paper is organised as follows. Section 2 provides institutional background for the study. Section 3 provides an empirical prediction for this study. Section 4 describes the data and research methodology. Section 5 discusses the empirical findings. Section 6 concludes.

\section{Institutional Background}

\subsection{Development of Financial Reporting in Malaysia}

\subsubsection{IFRS Adoption in Malaysia}

Malaysia’s early adoption of international accounting standards (IAS) occurred between 1978 and 1997. At this time, the Malaysia Accounting Standards Board (MASB) standards were in line with those issued by the International Accounting Standards Board (IASB), and had been modified to suit the local environment. In 1997, the MASB became the legal standard for all firms, and was enforced by the Firms Act 1965 and by other acts to cover specialised industries such as insurance.

Malaysia's convergence of local standards with IFRS is seen as a step towards enhancing transparency and making firms and various stakeholders aware of the 
importance of faithful and truthful reporting of financial statements. MASB chairman, Dato’ Zainal Abidin Putih, in one of his speeches on Malaysia’s full convergence to IFRS, noted that because Malaysia had been incorporating the provisions of international standards into its local standards since 1978, and that this standard was used by more than one hundred countries, adoption of full IFRS would facilitate comparability and increase transparency (PricewaterhouseCoopers, 2009). In 2005, in support of the IFRS issued by the IASB, the MASB standards were renamed the MASB standards for Financial Reporting Standards (FRS), and these were intended to be in line with standards issued by the IASB, except for some minor modifications. In January 2006, all Malaysia’s listed firms were required to adopt reporting standards with IFRS by preparing financial statements according to the IFRS. Since then, Malaysian FRS standards have been identical to IFRS and IAS. The difference between Malaysian FRS and IFRS lies in the standards that Malaysia has not adopted. Instead of adopting the entire standard to prepare financial statements, Malaysia has a twotiered financial reporting framework whereby the FRS framework is mandatory for non-private entities only; private entities can continue to use the old MASB standards, known as the private entity reporting standards framework.

To ensure compliance with IFRS in Malaysia, IFRS has been incorporated into law and regulations. Section 7 of the Financial Reporting Act 1997 empowers MASB to issue approved accounting standards for application in Malaysia. The form and content of the financial statements are specified in the Ninth Schedule of the Companies Act. However, where there is a conflict with the approved accounting standards, the accounting standards prevail. Under section 26D of the Financial Reporting Act 1997, financial statements that are prepared or lodged with the Central Bank, Securities 
Commission or Registrar of Companies are required to comply with the standards issued by the MASB.

\subsection{Malaysia's Connections}

\subsubsection{Political Connections}

In Malaysia, the political influence in the capital market is significant, and for a long time, leading politicians have contributed to shaping the nature of major business deals, including those involving the privatisation of leading Government-Linked Companies (Vithiatharan \& Gomez, 2014). Faccio et al. (2006) find that 81 politically connected firms existed in Malaysia during 1997-2002, which is second only to the UK with 188 firms_considering the size of Malaysia’s capital market; this is a staggeringly high number. Contrary to popular belief, political connections in business dealings existed long before the introduction of the New Economic Policy in 1970. White (2004), who documents evidence of crony capitalism from 1955 to 1970, argues that the institutional structure at that time, which segregated Bumiputras as government servants and ethnic Chinese as businesses, led to crony capitalism, as Chinese businessmen sought connections with powerful Bumiputras individuals to protect their business interests. ${ }^{3}$

\subsubsection{Family Connections}

The influence and dominance of family presence and ownership in Malaysia is well documented (Claessens, 2000; Claessens \& Fan, 2003; Jaggi et al., 2009).

\footnotetext{
${ }^{3}$ One such example is the rise to prominence of T.H. Tan in 1950-1960. Tan was a founding member of the Malaysia Chinese Association and he used his connections with Tunku Abdul Rahman (Malaysia’s first Prime Minister) to secure trade with Japan in 1956. After the colonial period, a trusted businessmancum-politician was required to secure Japanese business and Tan was chosen; he led the Malaysian interest by developing a business presence in Penang, Malaysia (White, 2004).
} 
According to statistics in the South China Morning Post, Malaysia has the secondhighest percentage of family ownership of listed firms in the region after Indonesia (Jaggi et al., 2009).

There are some advantages to family firms. Customers have very high levels of trust and confidence in family firms, which are supportive, have a strong sense of belonging and manage rivalries and conflicts effectively. However, the concentration of shares in the hands of a family can lead to type-II agency problems, such as an expropriation of minority shareholders' interests and conflict between majority and minority shareholders (Carney, 2005; Cheung et al., 2006, Fan \& Wong, 2002; Filatotchev \& Mickiewicz, 2001; Hanazaki \& Liu, 2007). The negative influence of family firms increases in institutions where legal investor protection is weak (Hanazaki \& Liu, 2007). When ownership is less concentrated, Ali et al. (2007), Chen et al. (2008) and Wang (2006) find that founding family ownership is associated with higher earnings quality.

\subsubsection{Richest-Men Connections}

Although its existence is undeniable, minimal attention has been given to the influence of the group of richest men in Malaysia’s political economy. This elite group, which exists under the title of 'richest men', has gained power through share ownership in some of the large conglomerates. Most of the richest men are Chinese. The top ten Chinese-owned firms in Malaysia control 28.3 per cent of total market capitalisation (Khan, 2003). Their wealth monopoly, political close relationship and business culture have enabled these business leaders to survive even during the financial crisis of 19971998. Interestingly, some of these men have also become individual shareholders in the 
Minority Shareholder Watchdog Group in Malaysia. ${ }^{4}$ Malaysia’s institutional background with its emphasis on Bumiputras privilege has made it somewhat hostile to ethnic Chinese Malaysians. To establish their position among the Malays, Chinese businesses have responded in several ways. Those with mobile capital investments have moved away from active politics, they engage in high-risk, short-term speculative ventures and they have diversified overseas. Malaysia’s richest man, Robert Kuok Hock Nien, for example, has diversified his interests across Asia without any political favouritism. Others, such as Vincent Tan Chee Yioun from the property and gambling conglomerate Berjaya Group, seek direct political ties through the official Chinese party in the National Front coalition, the Malaysian Chinese Association (Pepinsky, 2008).

\section{Empirical Predictions}

\subsection{IFRS and Conditional Conservatism}

Competing views exist on the effect of IFRS on conditional conservatism. Andre et al. (2015) argue that, conceptually, IFRS is conditionally conservative. They argue that the implementation of IFRS includes various mechanisms that ensure the application of conditional conservatism, such as a recognition of probable liabilities versus the non-recognition of contingent assets (IAS 37). IFRS emphasises the fairvalue principle, which involves a process of asset or liability recognition, initial measurement at fair value, re-measurement (again, largely, at fair value) and de-

\footnotetext{
${ }^{4}$ Five of the richest men in Malaysia have been appointed as individual shareholders in the Minority Shareholders' Watchdog Group: Robert Kuok, Ananda Krishnan, Quek Leng Chan, Syed Mokhtar Albukhary and Vincent Tan Chee Yioun.
} 
recognition. Based on this principle, losses are valued at market value, which increases conservatism among managers. ${ }^{5}$ Because the natural behaviour of humans is to disclose good news rather than bad, recognition of losses is considered important in increasing transparency. The IFRS introduced relatively more stringent and systematic impairment testing rules that rely on fair value estimates rather than local generally accepted accounting principles (Andre et al., 2015).

In contrast, the increased use of fair value of accounting leads to an overstatement of assets and consequently, to less accounting conservatism. Elshandidy and Hassanein (2014) argue that the treatment of conservatism is based on uncertainty in which the implementation of IFRS limits this uncertainty, and in turn is less conservative. Barth et al. (2008) argue that the adoption of IFRS could eliminate possible accounting alternatives that managers could use to demonstrate the economics of the business to stakeholders. Further, Barth et al. (2008) argue that the principal-based approach by IFRS lacks detailed implementation guidance and thus affords managers greater flexibility.

In addition to uniformity in IFRS, the timely loss recognition of earnings conservatism also reveals an important function of conservatism, which ensures that all possible losses are recognised before making a distribution, and that a distribution to parties with a prior contractual claim, such as creditors, is met. Evidence on the effect of IFRS on conditional conservatism is rather mixed. Lara et al. (2008) consider whether the use of IASB standards affects the conservatism of earnings of firms that adopt them. Their results show that earnings conservatism is more pronounced in

\footnotetext{
${ }^{5}$ The fair value principle is 'the amount for which an asset could be exchanged, or a liability settled, between knowledgeable, willing parties in an arm's length transaction'(Riahi-Belkoui, 2004).
} 
common law-based developed economies and that the voluntary use of IASB standards in Europe (prior to 2005) increased measures of earnings conservatism significantly.

Based on 13,711 firm-year observations from 16 European countries during 2000-2010, Andre et al. (2015) find an overall decline in conditional conservatism after the adoption of IFRS. A similar study by Zeghal et al. (2012) indicates that firms are less timely after the mandatory adoption of IFRS in 15 European countries, although they find no significant difference between adopters and non-adopters in conservative earnings. Elshandidy and Hassanein (2014) find a reduction in accrual-based conditional conservatism for Financial Times Stock Exchange 100 non-financial firms between 2002 and 2007 after the mandatory adoption of IFRS. In contrast, Lara et al. (2008) find that voluntary adoption of international accounting standards before 2005 among European countries results in an increase in conditional conservatism.

Based on mixed arguments and the results presented above, we posit, in the null form, a non-directional hypothesis:

$H_{1}$ : No relationship exists between IFRS convergence and conditional conservatism

\subsection{IFRS, Institutional Variables and Conditional Conservatism}

\subsubsection{Political Connections}

Competing views exist on the relationship between politically connected firms and earnings quality. The first view posits a negative effect on earnings quality, based on several arguments. The first is the complexity of income generated by political connections, which creates a certain level of uncertainty (Chen et al., 2011). Second, as argued by Bhattacharya et al. (2003), political connections are often linked to greater opacity in a firm. Assistance from the government allows managers a certain amount 
of discretion in financial disclosure. Third, connected firms are in less need of public funds (Faccio et al., 2006). Fourth, politically connected firms are associated with poor corporate governance and are vulnerable to the demands of political agendas and agency (Boubakri et al., 2013). Riahi-Belkaoui (2004) argues that managers of politically connected firms seek more aggressive forms of opportunism that may have important economic consequences, and that managers in politically connected firms camouflage their performance, which leads to an increase in earnings opacity. Baloria (2014) argues that politically connected firms adopt less conservative accounting because their stakeholders are less concerned with the risk of default. Bushman and Piotroski (2006) argue on the role of government in an imperfect market and that government intervention is required when insufficient economic institutions exist to play a significant role in the capital market. If this argument holds, when government intervenes with inefficient firms, those firms have an incentive to appear healthier through the application of less conservative accounting (Bushman \& Piotroski, 2006).

Johnson and Mitton (2003) find that politically connected public firms in Malaysia have significantly better returns even under capital control, which leads to less public demand for informative financial statements. In addition, political connections facilitate firms' receipt of privileged information, and any information asymmetry between shareholders and managers is settled through 'insider communication' rather than through 'public disclosure'. This type of political economy enables corporate entities in Malaysia to seek capital funding from 'insiders' rather than 
from the capital market. ${ }^{6}$ This situation creates less incentive for those preparing financial statements to adopt IAS.

The second view predicts a positive relationship between politically connected firms and earnings conservatism, in that those firms will adopt more conservative earnings to protect politicians from voter scrutiny as to whether the company incorporated bad news or good news in their financial statements (Bushman \& Piotroski, 2006; Watts, 2003). The constituents are more concerned with the inclusion of bad news in financial statements rather than good news, such that future sudden loss can be avoided. Political cost may be reduced because firms that underreport earnings may have less chance of being charged in court for misleading investors (Bushman \& Piotroski, 2006).

IFRS suggests that better accounting practice limits managerial discretion, such as a recognition of probable liabilities and a non-recognition of contingent assets in IAS 37, a lower cost or net realizable value for inventories (IAS 2) and an impairment of assets in IAS 36. Compared with local generally accepted accounting principles, IFRS introduces more stringent and systematic impairment testing rather than amortization based on judgement.

According to Guay and Verrecchia (2006), in a more stringent institutional setting, it is costly to adjust reported accounting numbers. Therefore, there is a reported bias toward more conservative rather than aggressive accounting numbers. Therefore,

\footnotetext{
${ }^{6}$ Sejati (2009) documents anecdotal evidence of benefits obtained from political connections. In 1987, the Jalan Kuching-Jalan Kepong interchange was contracted to Seri Angkasa Sdn. Bhd, which had no experience in the construction business. The firm allegedly won the contract because its owners included the brother of Daim Zainuddin, then Malaysia’s Finance Minister. In 1988, Pan Malaysia Sweeps Sdn. Bhd, a company owned by T. Ananda Krishnan, a close associate of former Prime Minister Tun Mahathir, was awarded the privatized Big Sweep lottery license, with the right to sell tickets to the public (Sejati, 2009). More recent evidence includes the National Feedlot Corporation contract that was awarded to the husband of a former minister.
} 
the negative (positive) impact of politically connected firms on earnings conservatism will be less (more) after convergence. Riahi-Belkaoui (2004) investigates the relationship between politically connected firms and earnings opacity and finds a negative relationship in a sample of 32 countries. Chaney et al. (2011) document that the quality of earnings reported by politically connected firms is significantly poorer than that of similar non-connected firms; they argue that the poor earnings quality arises from a weaker response to market pressure that allows these firms the luxury of disclosing lower-quality accounting information. Baloria (2014) examines the association between politician ownership and accounting conservatism in a sample of Standard \& Poor's 1500 firms between 2005 and 2011 and finds that equity ownership by members of the US House and Senate is associated with lower levels of conditional conservatism. Based on these discussions, we do not predict a directional effect of political connections on conditional conservatism post-IFRS and thus state a null hypothesis as follows:

$\mathrm{H}_{2}$ : There is no relationship between conditional conservatism and political connection post-IFRS convergence

\subsubsection{Ethnicity}

Ethnic research is tailored closely with the early development of the capital market in Malaysia. Because the development of the capital market is based loosely on racial grounds, studies have considered different groups with access to preferential government treatment. Bumiputras or Malays are related closely to government because of Malaysia’s New Economic Policy and therefore Bumiputras directors tend to be more politically connected and open to cronyism (Abdul Wahab et al., 2007; Johl 
et al., 2012). Johnson and Mitton (2003) state that the government's preferential treatment of Malay families includes government contracts, access to capital and other subsidies. Thus, the characteristic of Bumiputras firms is also related closely to politically connected firms. Previous research documents that Bumiputras-controlled firms and politically connected firms are often cited for poor performance and poor corporate governance practice in Malaysia (Johnson \& Mitton, 2003; Gul, 2006; Yatim et al., 2006).

In contrast with Malay firms, Chinese firms emphasise family business networks. Research on Chinese businesses and entrepreneurs (Kao, 1995; Weidenbaum \& Hughes, 1996) emphasises that ethnic Chinese businesspersons have developed codes of conduct with a strong hierarchical power. Decisions come from the top, and those in lower positions are extremely cautious about how they present ideas to top management (Crookes \& Thomas, 1998). Family members are well looked after and are compensated for their loyalty and trust (Haley \& Tan, 1999). Chinese and Indian managers are less likely to support government policies (Mamman, 2003). This is because intervention from the government creates political costs for firms that are controlled by minority ethnic Chinese. The situation provides incentives for them to avoid reporting high profits (Ball et al., 2003), whereas Malay-controlled firms depend heavily on government support and thus they are not afraid of becoming insolvent. These firms may not be motivated to produce good or sound financial reporting because of their government support (Faccio et al., 2006).

The effect of Bumiputras firms is well documented in previous research. Gul (2006) examines the relationship between political connections and audit fees in Malaysia, in which he uses Bumiputras directors as a proxy for connected firms. Johl 
et al. (2012) investigate the characteristics of chief executive officer ethnicity and audit fees and find a connection between ethnicity and government intervention. Abdul Wahab et al. (2014) adopt a similar approach in examining the issue of non-audit fees and auditor independence. Their premise is that the preferential treatment of connected firms, proxied by Bumiputras directors, leads to a riskier and more inefficient firm. This is supported by financial reporting quality studies such as that of Bushman et al. (2004) and the possibility of government bailout of connected firms (Faccio et al., 2006). Based on the mixed arguments, we do not predict a directional effect of Bumiputras directors and conservatism post-IFRS and thus state a null hypothesis as follows:

$\mathrm{H}_{3}$ : There is no relationship between conditional conservatism and the proportion of Bumiputras directors’ post-IFRS convergence

\subsubsection{Family Connections}

Wang (2006) argues that the demand and supply of quality earnings in family firms depends on two competing factors. The first is the entrenchment effect, whereby an increase in ownership concentration increases the risk of the expropriation of minority interests. Because family firms are characterised by a high ownership by family members, the supply of quality earnings is low. Bertrand and Schoar (2006) offer several characteristics that may make these firms inefficient. The first is that family ties could lead to nepotism: a business that relies on family kinship dampens growth as it loses the ability to seek external financial and human resource assistance. The second is legacy: the founders of a family business aim to ensure that the business remains in the family. These characteristics suggest a supply of low-quality earnings. 
However, the entrenchment effect could also signal a high demand for quality earnings from shareholders and various stakeholders, such as debtholders (Wang, 2006).

A second point raised by Wang (2006) is the alignment effect, which suggests that the interests of family and other shareholders are better aligned because the large block shareholders and their long-term presence increases the quality of accounting information.

Chen et al. (2014) argue that the unique characteristics of family firms lead to greater incentives for family owners to demand conservative reporting with the two drivers being agency and litigation costs. They argue that potential agency problems between debtholders and shareholders lead to a higher cost of capital. Because family firms are characterised by a multi-generation investment horizon and lack of diversification, family owners bear these costs, and so have an incentive to implement conservative financial reporting. Chen et al. (2014) also argue that family firms bear a higher risk of litigation because of their concentrated ownership and lack of diversified holdings (Anderson \& Reeb, 2003; Chen et al., 2008). The desire to mitigate such risk leads family firms to report conservatively.

Evidence regarding the effect of family firms is rather inconclusive. Chen et al. (2008) and Wang (2006) find that founding family ownership is associated with a higher earnings quality. Chen et al. (2014) investigate the relationship between founding family ownership and conservatism. Based on 8264 firm-year observations in the Standard \& Poor's 1500 that covered a ten-year period from 1996 to 2005, they find that a positive relationship exists between non-chief executive officer founding ownership and earnings conservatism. Lim et al. (2014) investigate ownership structure and timeliness of earnings in Malaysia and find that family firms are less timely in price 
discovery. The convergence to IFRS is expected to enhance the alignment effect of family firms by limiting managers' discretion. To protect the long-term survival and long investment horizon in family ownership, indirectly, the enforcement of IFRS will help family firms mitigate agency costs and legal liability that will increase their span for multiple generations. Based on these discussions, we do not predict a directional effect of family connections and conditional conservatism post-IFRS and thus state a null hypothesis as follows:

$\mathrm{H}_{4}$ : There is no relationship between conditional conservatism and family connections post-IFRS convergence

\subsubsection{Richest-Men Connections}

The presence of richest men in Malaysia’s political economy is less debatable but is significant. This elite group plays an important role, particularly in economic development, because of their economic power, wealth and political connections. According to Studwell (2008), the influence of this elite group grew slowly during the colonial era, and affected most of the South-East Asian economy. In the post-colonial era, this group was used by political powers to create a class of cronies who could afford to support them. With their elite political connections, this group generates enormous wealth and serves a political purpose without contributing to economic development.

Studwell (2008) explains that elite groups sustain the economy when political powers engage in significant economic development. Politicians who wish to maintain their power can spend huge sums of money, financed either through their political ownership or through contributions from independent, wealthy persons from big businesses. Firth et al. (2012) and He et al. (2012) examine the impact of the 
announcement of the richest-men list in China. It is argued in both papers that Confucian culture promotes collectivism, which translates to economic egalitarianism. The announcement of the rich list conflicts with the tenets of Confucian culture and results in 'resentment against the rich'. Firth et al. (2012) and He et al. (2012) suggest that the announcement of the list will affect share prices negatively, and both find that the announcement results in abnormal negative returns that persist for three years following the announcement.

Evidence, either anecdotal or empirical, on the richest men in Malaysia is scarce. These men are not politicians, but they support the government. We discern two different types of firms with richest-men connections. First, there are those that amass wealth via connections to politicians; these firms may have similar features to politically connected firms, including a riskiness, a lack of ability to secure outside funding, a lack of transparency and uncertainty about income-generation procedures. ${ }^{7}$ This argument suggests that firms with richest-men connections will have a low level of earnings quality.

A second type is firms that accumulate their wealth independently: they do not rely on government funding, and they generate their own income. These firms are likely to be transparent, promote good governance and have higher levels of accounting quality because these characteristics are required to attract investors. The contracting explanation (Baloria, 2014) on conservatism suggests that firms with a richest man as

\footnotetext{
${ }^{7}$ An example of such a person is Tan Sri Syed Mokhtar Albukhary, who is listed at seventh on the 2012 Forbes List. He owns majority shareholdings in several government-controlled firms: Tradewinds Bhd. (100\%), DRB-HICOM (55.92\%) and MMC (51.76\%). He acts as major shareholder for three firms because of his connection to DRB-HICOM: Proton, EON and Lotus. He also owns majority shareholdings in PadiBeras Nasional Berhad and Central Sugar Sdn. Bhd. We do not say that he obtained these firms via connections; our illustration shows that the government previously owned a majority of the firms owned by Tan Sri Syed Mokhtar Albukhary.
} 
a shareholder are motivated to implement higher earnings conservatism as the stakeholders are wary of the financial support or collateral the richest man could provide, and thus they demand a higher earnings quality. The political cost argument also suggests that firms could supply quality earnings as protection from legal liability. Based on these discussions, we do not predict a directional effect of richest-men connections on conditional conservatism post-FIRS and thus state a null hypothesis as follows:

$H_{5}$ : There is no relationship between earnings conservatism and the richestmen connections after IFRS convergence.

\section{Data and Research Methods}

\subsection{Sample Selection and Data Collection}

Our initial sample consists of 440 Bursa Malaysia-listed firms during 2004 2005 (pre-IFRS) and 2007-2008 (post-IFRS). ${ }^{8}$ Financial institutions, insurance companies and real estate firms are excluded as they operate under different regulatory frameworks. The data distribution is presented in Table 1. The year selection is based on the effective date for preparing financial statements based on IFRS for all Malaysianlisted firms, 1 January $2006 .{ }^{9}$

Data are extracted from Compustat Global. Some data are collected by hand, which makes them unique. The minimum data required for each year's firm observation are the current year's earnings, the previous fiscal year-end stock price, the book value of assets and equity and returns (Basu, 1997). Following Vichitsarawong et al. (2010)

\footnotetext{
${ }^{8} \mathrm{We}$ choose the same 440 firms over the period to investigate the impact of IFRS on earnings conservatism for pre- and post-periods of IFRS.

${ }^{9}$ We exclude data from 2006 as we consider this to be a transition year.
} 
and Ball et al. (2003), the accounting variables are deflated by the beginning of the period price to control for heteroscedasticity. Because of the cross-sectional time series effects, panel data is a more appropriate method than pooled ordinary least squares, which ignores the panel structure of the data and treats observations as being serially uncorrelated for a given firm, with homoscedastic errors across firms and time periods. Fixed effect panel data control is used for omitted variables that differ between cases but are constant over time (Balsari et al., 2010). The 1st and 100th percentiles of each variable are winsorised to reduce the effect of outliers. Finally, each firm-year observation with a missing value for any of the variables is excluded.

[Insert Table 1 here]

\subsection{Measurement of Conditional Conservatism}

Out first measure of conditional conservatism is based on Khan and Watts (2009) firm-year accounting conservatism measure (C_SCORE). Following Khan and Watts (2009), we estimate our first firm-year measure of conditional conservatism (BC_SCORE) by estimating Basu’s (1997) regression, as in Equation (1) and allow the coefficients to vary across firms and with time:

$$
N_{i t}=\beta_{0}+\beta_{1 i t} D R_{i t}+\beta_{2 i t} R_{i t}+\beta_{3 i t} R_{i t} * D R_{i t}+e_{i t}
$$

where $N_{i t}=$ net income before extraordinary items per share of firm i, deflated by the beginning of the period share price; $R_{i t}$ is the fiscal year continuously compounded return and $D R_{i t}$ is the dummy variable, which is equal to one if $R_{i t}$ is negative and is zero otherwise. The earning variable $N_{i t}$ is calculated as $X_{i t} / N_{i t} P_{i t-1}$ where $X_{i t}$ is the net 
income before extraordinary items for firm i, $N_{i t}$ is the adjusted number of shares and $P_{i t-1}$ is the share price.

In this model, stock returns is the independent variable and earnings is the dependent variable. The coefficient on stock returns $b_{2}$ measures the sensitivity of accounting income to positive stock returns (a proxy for economic gains). The coefficient $b_{3}$ is the main measurement for earnings conservatism, and measures the incremental sensitivity of accounting income to the incorporation of bad news as measured by negative stock returns (a proxy for economic losses). The total sensitivity of accounting income to negative stock returns is measured from $\left(b_{2}+b_{3}\right)$.

To estimate the timeliness of good and bad news at the firm-year level, Khan and Watts (2009) specify the timeliness of good news (G_SCORE) and the asymmetric timeliness of bad news (C_SCORE) and linear functions of firm-specific characteristics (leverage, size and the market-to-book ratio (MTB)) as follows:

$G \_S C O R E=b_{1 i t}=\mu_{1 t}+\mu_{2 t} S I Z E_{i t}+\mu_{3 t} M T B_{i t}+\mu_{4 t} L E V_{i t}$

C_SCORE $=b_{3 i t}=\lambda_{1 t}+\lambda_{2 t} S I Z E_{i t}+\lambda_{3 t} M T B_{i t}+\lambda_{4 t} L E V_{i t}$

where SIZE is the natural log of total assets, $M T B$ is the market value of equity divided by the book value of equity and $L E V$ is the total debt deflated by total assets. Therefore, Basu's (1997) regression can be rewritten as shown in (3) by substituting (2a) and (2b) into (1): 


$$
\begin{aligned}
& N_{i t}=\beta_{0}+\beta_{1 i t} D R_{i t}+R_{i t}\left(\mu_{1 t}+\mu_{2 t} S_{Z I Z} E_{i t}+\mu_{3 t} M T B_{i t}+\mu_{4 t} L E V_{i t}\right)+R_{i t} * D R_{i t}\left(\lambda_{1 t}+\lambda_{2 t} S I Z E_{i t}\right. \\
& \left.+\lambda_{3 t} M T B_{i t}+\lambda_{4 t} L E V_{i t}\right)+\left(\delta_{1 t} S I Z E_{i t}+\delta_{2 t} M T B_{i t}+\delta_{3 t} L E V_{i t}+\delta_{4 t} D R_{i t} * S I Z E_{i t}+\right. \\
& \left.\delta_{5 t} D R_{i t} * M T B_{i t}+\delta_{6 t} D R_{i t} * L E V_{i t}\right)+e_{i t}
\end{aligned}
$$

Recent studies subsequent to Khan and Watts (2009) such as Chen et al. (2014) and Lee et al. (2015) use this modified conservatism measure based on Basu (1997). We estimate annual regressions of Equation (3) and obtain coefficients of $\lambda_{1 t}, \lambda_{2 t}, \lambda_{3 t}$ and $\lambda_{4 t}$ to estimate C_SCORE (2b), which we denote C_SCORE. C_SCORE varies across firms through a cross-sectional variation in the firm-year characteristics (SIZE, $M T B$ and $L E V$ ) and over time through intertemporal variation in $\lambda$. Conditional conservatism increases with increase in C_SCORE. Because many other studies criticize Basu's (1997) measure as having econometric biases (e.g., Dietrich et al., 2007; Patatoukas \& Thomas, 2011), we measure conditional conservatism beyond Khan and Watts' (2009) modified conservatism measure based on Basu’s (1997) work to ensure the robustness of our findings. The measure we use is based on the Ball and Shivakumar (2005) accruals-based loss recognition model. We modify this measure using the methodology that Khan and Watts (2009) adopt to estimate a firm-year measure of conservatism. The model from Ball and Shivakumar (2005) is outlined in Appendix A.

\subsection{IFRS and Earnings Conservatism}

We use the model given by (4) to test the relationship between IFRS convergence and earnings conservatism: 
$C \_S C O R E_{i t}=\beta_{0}+\beta_{1} I F R S_{i t}+\beta_{2} S_{Z} Z E_{i t}+\beta_{3} M T B_{i t}+\beta_{4} L E V_{i t}+\beta_{5} B I G 4_{i t}+\sum \beta_{j} P E R I O D_{i t}$ $+\sum \beta_{k} I N D U S T R I E S_{i t}+\varepsilon_{i t}$

IFRS is the dummy variable, which is equal to 1 for the period after IFRS and is 0 otherwise. Similar to Ahmed and Duellman (2013), we control for firm size (SIZE) because Givoly et al. (2007) document that larger firms have a lower asymmetric timeliness of earnings. In addition, we control MTB because Roychowdhury and Watts (2007) find that asymmetric timeliness is related to the level of conservatism since the inception of the firm and it controls the extent of growth opportunities (Gul, 1999; Hutchinson \& Gul, 2004). Next, we control for leverage (LEV) because Ahmed et al. (2002) find that firms with a greater level of leverage had higher levels of conservatism. We include the auditor size and proxy by Big 4 auditors (BIG4), for which we predict a positive relationship. We include period (PERIOD) and industries (INDUSTRIES) fixed effects to control for unobserved effects during the period, and variations of conservatism across industries.

\subsection{Regression models ${ }^{10}$}

We offer three models. The first depicts the composition (Model 1), whereas the second and third represent the direct (Model 2) and indirect (Model 3) ownership of our institutional variables, respectively. The rationale behind this approach is to provide different dimensions of our results.

\footnotetext{
${ }^{10}$ For brevity, we present the full regressions based on Basu's model only.
} 


\subsubsection{Composition}

The first model is the 'composition' model. The premise of the construction of this model is to identify whether the characteristics of the firms influence earnings conservatism. The regression for Model 1 is as follows:

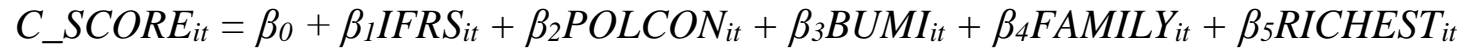
$+\beta_{6}$ POLCON*IFRS $_{i t}+\beta_{7}$ BUMI*IFRS $_{i t}+\beta_{8}$ FAMILY*IFRS $_{i t}+\beta_{9}$ RICHEST $^{*} I F R S_{i t}+$ $\beta_{10}$ SIZE $_{i t}+\beta_{11}$ MTB $_{i t}+\beta_{12} L E V_{i t}+\beta_{13} B_{G} 4_{i t}+\sum \beta_{j} P E R I O D_{i t}+\sum \beta_{k} I_{N D U S T R I E S}+\varepsilon_{i t}$

where POLCON has a value of 1 if the firm is connected to a politician or political party, as suggested by Johnson and Mitton (2003). BUMI is the proportion of Bumiputras on the board of directors; this variable is similar to that used by Gul (2006) and Abdul Wahab et al. (2014). FAMILY is an indicator variable that has a value of 1 if the firm has a family connection (Wan-Hussin, 2009). RICHEST is a dichotomous variable that has a value of 1 if the firm has at least one of the richest men as a shareholder. ${ }^{11}$ The intuition for the control variables, SIZE, MTB, LEV, PERIOD and INDSUTRIES, is similar to that discussed in Section 4.3.

\subsubsection{Direct Ownership}

The second model presents direct ownership for family (FM_DIRECT) and richest man (RC_DIRECT). This information is gathered from shareholding information in annual reports. The rationale behind this approach is to provide a different dimension to our analysis by examining direct ownership and its effect on

\footnotetext{
${ }^{11}$ Please see appendix A for a list of the richest men in Malaysia.
} 
earnings conservatism. Further, it is known that in Malaysia, firms are controlled by a small group of related parties and are managed by owner-managers (Claessens et al., 1999) and thus lie in the hands of controlling owners who are placed to monitor its management. Because a large part of shareholder wealth is often tied directly to the firms, the shareholders usually have strong incentives to monitor the firm closely. This suggests that ownership concentration can reduce agency conflicts and the demand for conservative earnings (Bona-Sanchez et al., 2011). Similar to the argument in Section 3.2.3, IFRS convergence enhances the alignment effect and limits managerial discretion, and thus enhances conservatism.

The intuition for the control variables, SIZE, MTB, LEV, PERIOD and INDUSTRIES, is similar to that discussed in Section 4.3. The regression for Model 2 is as follows:

$$
\begin{aligned}
& C \_S C O R E_{i t}=\beta_{0}+\beta_{1} I F R S_{i t}+\beta_{2} P O L C O N_{i t}+\beta_{3} B U M I_{i t}+\beta_{4} F M_{-} D I R E C T_{i t}+ \\
& \beta_{5} R C \_D I R E C T_{i t}+\beta_{6} P O L C O N * I F R S_{i t}+\beta_{7} \text { BUMI }^{*} I F R S_{i t}+\beta_{8} F_{-} \_D I R E C T^{*} I F R S_{i t}+ \\
& \beta_{9} R C \_D I R E C T^{*} I_{F R S}+\beta_{10} S I Z E_{i t}+\beta_{11} M_{T H} B_{i t}+\beta_{12} L E V_{i t}+\beta_{13} B I G 4_{i t}+\sum \beta_{j} P E R I O D_{i t} \\
& +\sum \beta_{k} I N D U S T R I E S_{i t}+\varepsilon_{i t}
\end{aligned}
$$

\subsubsection{Indirect Ownership}

Similar to the direct ownership model 2, we opt for a model that measures indirect ownership in Malaysia. Because Malaysian ownership is dominated by a pyramidal style (Claessens \& Fan, 2002), we create indirect ownership variables for family (FM_INDIRECT) and richest men (RC_INDIRECT) from information that is gathered from annual reports. The intuition for the control variables, SIZE, MTB, $L E V$, 
PERIOD and INDUSTRIES, is similar to that discussed in Section 4.3. The regression for Model 3 is as follows:

C_SCORE $i t=\beta_{0}+\beta_{1}$ IFRS $_{i t}+\beta_{2}$ POLCON $_{i t}+\beta_{3} B U M I_{i t}+\beta_{4} \mathrm{FM}_{-} I N D I R E C T_{i t}+$ $\beta_{5} R C \_I N D I R E C T_{i t}+\beta_{6} P O L C O N * I F R S_{i t}+\beta_{7} B U M I * I F R S_{i t}+$ $\beta_{8} F M_{-} I N D I R E C T^{*} I F R S_{i t}+\beta_{9} R C \_I N D I R E C T^{*} I F R S_{i t}+\beta_{10} S I Z E_{i t}+\beta_{11} M B_{i t}+$ $\beta_{12} L E V_{i t}+\beta_{13} B I G_{i t}+\sum \beta_{j} P E R I O D_{i t}+\sum \beta_{k} I_{N D U S T R I E S}+\varepsilon_{i t}$

Table 2 provides the operational definition of variables used in this study.

[Insert Table 2 here]

\subsection{Sample Description}

Panel A of Table 3 presents descriptive statistics for the dependent variables; pre- and post-IFRS periods. The mean (median) C_SCORE pre-IFRS is -6.783 (-7.430) whereas post-IFRS, the C_SCORE mean (median) value is 6.866 (-23.768). Mean (ttest) and median (Mann-Whitney) tests indicate a significant difference for the C_SCORE pre- and post-IFRS periods. The mean (median) for our alternative measure of conditional conservatism yields an AC_SCORE of $0.023(0.000)$ pre-IFRS and 0.028 (0.000) post-IFRS, which is an insignificant difference.

Panel B of Table 3 tabulates descriptive statistics for the institutional variables. The percentage of sample firms that are politically connected (POLCON) equates to 38.6\%, whereas $60 \%$ of firms have family connections (FAMILY). The mean (median) direct family ownership (FM_DIRECT) pre-IFRS is $5.453(0.105) \%$ and post-IFRS is 
6.657 (0.177)\%. The mean (median) indirect family ownership (FM_INDIRECT) is $16.605(0.000) \%$ pre-IFRS and $16.553(0.000) \%$ post-IFRS. T-tests and Mann-Whitney tests of differences pre- and post-IFRS indicate an insignificant difference between results.

Ten percent of sample firms have at least one richest man (RICHEST) as their shareholder. The mean (median) for direct richest-men shareholdings (RC_DIRECT) is $0.717(0.000) \%$ pre-IFRS and $0.866(0.000) \%$ post-IFRS. The mean (median) for indirect richest-men shareholdings (RC_INDIRECT) is $3.898(0.000) \%$ pre-IFRS and $3.565(0.000) \%$ post-IFRS. The t-test and Mann-Whitney tests indicate an insignificant difference for RC_DIRECT and RC_INDIRECT results pre- and post-IFRS.

Panel C of Table 3 tabulates the descriptives for the control variables. The firm size (SIZE) records a mean (median) of 19.802 (19.748) during the pre-IFRS period, whereas a mean (median) of 19.693 (19.573) results post-IFRS. The t-test and MannWhitney test of differences yield a significant difference in results. The market-to-book (MTB) has a mean (median) of $0.703(0.490)$ pre-IFRS and a mean (median) of 1.264 (0.874). Similar to SIZE, the MTB test of differences yields significant findings from the t-test and Mann-Whitney test. LEV averages (median) of 0.419 (0.394) pre-IFRS and $0.420(0.411)$ post-IFRS result, with insignificant differences from the t-test and Mann-Whitney test. Approximately 57.7\% of sample firms were audited by a Big 4 audit firm (BIG4) pre-IFRS and $64.2 \%$ post-IFRS, in which the $\chi 2$ result suggests an insignificant difference between those two periods.

[Insert Table 3 here] 


\section{Results}

\subsection{Correlations}

Table 4 presents correlations for the variables in this study and includes Pearson and Spearman-rank (italicised) correlations. Negative and significant correlations occur between C_SCORE and RICHEST for the Pearson (-0.050) and Spearman-rank (0.090), and these are significant at the $5 \%$ and $1 \%$ levels respectively. No significant correlations result between $C \_S C O R E$ and other institutional variables for the Pearson correlations. However, a significant Spearman-rank correlation results against C_SCORE for FAMILY (0.075), FM_DIRECT (0.088), FM_INDIRECT (0.065), RC_DIRECT (-0.100) and BUMI (0.062), at a 1\% level, with the exception of BUMI, which was at a $5 \%$ level.

A negative and significant Pearson correlation results between POLCON and AC_SCORE (-0.045), at the 10\% level. However, no significant Pearson correlations exist between C_SCORE and the remaining institutional variables. We document significant Spearman-rank correlations against AC_SCORE for FAMILY (0.061), FM_DIRECT (0.084) at the $1 \%$ level and RC_DIRECT $(-0.058)$ at the $5 \%$ level. Other correlations between independent variables are relatively low and do not appear to suggest that multicollinearity is problematic in this study.

\section{[Insert Table 4 here]}

\subsection{Multivariate}

\subsubsection{IFRS and Earnings Conservatism}

Table 5 presents the main regression results that examine the impact of IFRS on conditional conservatism. Column 1 of Table 5 tabulates the regression for C_SCORE 
in which we find a positive and significant coefficient for IFRS (10.842, $t=2.396, p<$ 0.05). Our alternative measure, AC_SCORE, which is a variation of Khan and Watts (2009) for Ball and Shivakumar's (2005) accrual-based loss recognition, shows similar results for IFRS $(0.001, t=2.358, p<0.05)$. Our findings support the argument that IFRS enhances conservatism.

A significant and negative relationship exists between SIZE and C_SCORE, which supports the argument raised by Givoly et al. (2007) that larger firms have a lower asymmetric timeliness of earnings. Contrary to prediction, a negative and significant relationship exists between LEV and C_SCORE and AC_SCORE.

\section{[Insert Table 5 here]}

\subsubsection{Composition}

Table 6 tabulates our first model that focuses on the composition of the firm. Column 1 of Table 6 presents the C_SCORE regression, with positive and significant coefficients for IFRS (29.530, $t=2.215, p<0.05)$. Positive and significant coefficients exist for $B U M I^{*} I F R S(0.383, t=2.171, p<0.05)$, which suggests that firms with Bumiputras directors are more conservative after IFRS convergence. In addition, a negative and significant coefficient results for RICHEST*IFRS $(-28.021, t=-1.895, p$ $<0.10$ ). This suggests that even after the convergence of IFRS in 2006, firms with at least one richest man as shareholder are less conservative.

Column 2 of Table 6 presents the AC_SCORE regression. We find that firms with family connections (FAMILY) are related positively to accrual-based loss recognition (0.011, $t=3.117, p<0.01)$, but are less conservative after IFRS convergence $(-0.008,-1.746, p<0.10)$. Similar to our findings in column 1 of Table 
6, firms with at least one richest man as shareholders are less conservative after convergence in 2006. The variance inflations factors (VIFs) for columns 1 and 2 are 3.363 and 8.451 respectively, which suggests no multicollinearity problem in the regressions. $^{12}$

[Insert Table 6 here]

\subsubsection{Direct Ownership}

Table 7 presents the regressions for our second model, direct ownership. Column 1 of Table 7 tabulates the regression based on C_SCORE, whereas Column 2 shows the AC_SCORE. IFRS is positive and is associated significantly with both of our measures of conditional conservatism (C_SCORE: 35.871, $t=2.730, p<0.01$; AC_SCORE: $0.002, t=1.767, p<0.10$ ). In contrast with our findings in column 2 of Table 6, we find that direct family ownership (FM_DIRECT) is negatively and significantly associated with AC_SCORE $(0.000, t=-2.687, p<0.01)$. Similar to Table 6, positive and significant coefficients for $B U M I^{*} I F R S$ as presented in columns 1 $(0.350, t=2.022, p<0.05)$ and $2(0.000, t=1.754, p<0.10)$ of Table 7 suggest that firms with a high level of Bumiputras directors are more conservative after IFRS convergence in 2006. Our interaction term FM_DIRECT*IFRS is positively and significantly related to AC_SCORE $(0.000, t=2.020, p<0.05)$ and this suggests that family firms proxied by direct ownership are more conservative after IFRS convergence. The VIFs for columns 1 and 2 in Table 7 are 3.362 and 4.405, respectively, which suggests that the regressions do not suffer from multicollinearity issues.

\footnotetext{
12 As suggested by Neter et al. (1983), a VIF that is greater than 10 can be seen as a sign of multicollinearity.
} 
[Insert Table 7 here]

\subsubsection{Indirect Ownership}

Table 8 presents the regressions for our third model that measures indirect ownership. Positive and significant coefficients result for IFRS in column 1 (C_SCORE, 35.603, $t=2.678, p<0.01$ ) and column 2 (AC_SCORE, 0.003, $t=2.206$, $p<0.05)$. BUMI is negatively and significantly associated with our measures of conditional conservatism (C_SCORE: $-0.250, t=-1.836, p<0.10$; AC_SCORE: -0.000 , $t=-2.090, p<0.05)$. Similar to Tables 6 and 7 , the interaction term BUMI*IFRS is positive and is associated significantly with our measures of conservatism (C_SCORE:0.412, $t=2.365, p<0.05$; AC_SCORE: 0.000, $\mathrm{t}=1.772, p<0.10$ ).

Our indirect family ownership measure (FM_INDIRECT) is positive and significant after IFRS convergence $\left(C \_S C O R E: 0.388, t=1.780, p<0.10\right)$ and this suggests that firms with a high level of indirect family ownership are more conservative after IFRS convergence. In contrast, a negative and significant relationship results between indirect ownership by richest men after IFRS (RC_INDIRECT*IFRS) and C_SCORE (-0.692, $t=-2.025, p<0.05)$. The VIFs for columns 1 and 2 for Table 8 are 3.377 and 5.356, respectively.

[Insert Table 8 here]

Table 5 examines the relationship between IFRS and conditional conservatism. Tables 6, 7 and 8 are models that examine the relationship between composition, direct 
ownership and indirect ownership and measures of conditional conservatism, respectively. We find consistent results across various models, which indicate that the firms are more conservative after IFRS convergence in 2006. Our models do not indicate that any relationship exists between politically connected firms and conditional conservatism.

Our analysis of family firms yields mixed results. The composition model presented in Table 6 shows that firms with family connections are less conservative after IFRS convergence. Nevertheless, the extended analyses, which examine direct (Table 7) and indirect (Table 8) ownership, respectively, show that these firms are more conservative post-IFRS convergence. The results support the view by Chen et al. (2014) that highlight the role of family ownership as an incentive to family members to influence financial reporting quality. The large equity ownership of the family members' results in their greater involvement in the firm's daily operation and hence greater conservative accounting is demanded to protect the firms from litigation costs.

The next institutional variable is the richest men in Malaysia. As shareholders, firms with at least one richest man are less conservative post-IFRS, and this is supported when we test for indirect richest-men ownership as presented in Table 8. The result suggests that richest men amass their wealth through connections to politicians. Therefore, they tend to pay less attention to the regulation as they may have government support. According to Studwell (2008), the exercise of power of the elite group is facilitated by their close relationship with politicians and the government, which enables them to use this connection to accumulate wealth even with a minimal contribution to Malaysia’s economy. In political economy theory, which emphasizes 
the relationship between economics and politics in nation states or across different nation states, these two parties are interdependent for survival in their careers.

\section{Conclusion}

We investigate the impact of convergence with IFRS on earnings conservatism by studying the role of Malaysian institutional variables that could affect earnings conservatism in periods prior to and after convergence with IFRS. Based on data from 440 firms (1760 firm-year observations) during 2004-2005 (pre-IFRS) and 2007-2008 (post-IFRS), we find that convergence in Malaysia enhances earnings conservatism, based on measures of the Basu (1997) method and accrual-based loss recognition. Therefore, convergence to IFRS improves financial reporting transparency by enhancing earnings conservatism.

Despite the positive effect of IFRS on earnings conservatism, our extended analysis on the relationship between institutional factors, IFRS and earnings conservatism reveals that the positive effect of IFRS is likely limited if some factors remain unchanged. Based on our findings, we conclude that, to a large extent, reporting practices in Malaysia are determined by institutional factors such as legal and enforcement systems and firm-level factors such as ownership structures and governance.

Family firms are suggested to be less conservative after IFRS. A relationship exists between direct and indirect family ownership and conservatism post- IFRS convergence. Therefore, family firms have incentives to promote good governance and to protect the interests of family members to ensure the future sustainability of their firms. The incentives of indirect ownership provided by the family firms have enhanced the financial reporting quality among family firms after IFRS convergence. The 
variable that indicates that the firm has at least one richest man as a shareholder indicates that firms are less conservative after convergence. 


\section{References}

Abdul Wahab, E. A., How, J. C. Y., \& Verhoeven, P., 2007, "The Impact of the Malaysian Code on Corporate Governance: Compliance, Institutional Investors and Stock Performance", Journal of Contemporary Accounting \& Economics, 3(2), 106-129.

Abdul Wahab, E. A., Mat Zain, M., \& Abdul Rahman, R., 2015,"Political Connections: A Threat to Auditor Independence?",Journal of Accounting in Emerging Economies, 5(2), 222-246.

Abdul Wahab, E. A., Gist, W. E., \& Nik Abdul Majid, W. Z.,2014,"Characteristics of Non-audit Services and Financial Restatements in Malaysia",Journal of Contemporary Accounting and Economics, 10(3), 225-247.

Ahmed, A. S., \& Duellman, S., 2007, "Accounting Conservatism and Board of Director Characteristics: An Empirical Analysis", Journal of Accounting and Economics, 43, 411-437.

Ahmed, A. S., \& Duellman, S.,2013,"Managerial Overconfidence and Accounting Conservatism",Journal of Accounting Research, 51(1), 1-30.

Ahmed, A. S., Billings, B. K., Morton, R. M., \&Stanford-Harris, M., 2002, “The role of accounting conservatism in mitigating bondholder-shareholder conflicts over dividend policy and in reducing debt costs”, The Accounting Review, 77(4), 867890.

Anderson, R. C., \& Reeb, D. M., 2003, "Founding-Family Ownership and Firm Performance: Evidence from S\&P 500", Journal of Finance, 53(3), 1301-1328.

André, P., Filip, A., \& Paugam, L,2015, "The Effect of Mandatory IFRS Adoption on Conditional Conservatism in Europe”, Journal of Business Finance \& Accounting, 42(3-4), 482-514.

Ali, A., Chen, T.Y. \& Radhakrishnan, S., 2007, "Corporate Disclosures by Family Firms", Journal of Accounting and Economics, 44(1-2), 238-286.

Ball, R., Kothari, S. P., \& Robin, A., 2000, "The Effect of International Institutional Factors on Properties of Accounting Earnings", Journal of Accounting and Economics, 29, 1-51.

Ball, R., Robin, A., \& Shuang Wu, J., 2003, "Incentives versus Standards: Properties of Accounting Income in Four East Asian Countries", Journal of Accounting and Economics, 36, 235-270.

Ball, R., \& Shivakumar, L., 2005, "Earnings Quality in UK Private Firms:Comparative Loss Recognition Timeliness", Journal of Accounting and Economics, 39, 83128.

Balsari, C. K., Ozkan, S., \& Durak, G., 2010, "Earnings Conservatism in Pre-and PostIFRS Periods in Turkey: Panel Data Evidence onthe Firm Specific Factors. Accounting and Management Information Systems", 9(3), 403

Baloria, V. (2014). Politicians' Equity Holdings and Accounting Conservatism.

Barth, M. E., Landsman, W. R., \& Lang, M. H., 2008, "International Accounting Standards and Accounting Quality”, Journal of Accounting Research, 46(3), 467498.

Basu, S., 1997, "The Conservatism Principle and the Asymmetric Timeliness of Earnings", Journal of Accounting and Economics, 24, 3-37. 
Bertrand, M., \& Schoar, A., 2006, "The Role of Family in Family Firms", The Journal of Economic Perspectives, 20(2), 73-96.

Bhattacharya, U., Daouk, H., \& Welker, M., 2003, "The World Price of Earnings Opacity", The Accounting Review, 68 (3), 641-678.

Black, E. L., \& White, J. J., 2003, "An International Comparison of Income Statement and Balance Sheet Information: Germany, Japan andthe US", European Accounting Review, 12(1), 29-46.

Bona-Sánchez, C., Pérez-Alemán, J., \& Santana-Martín, D. J. (2011). Ultimate Ownership and Earnings Conservatism. European Accounting Review, 20(1), 5780.

Boubakri, N., Mansi, S. A., \& Saffar, W., 2013, "Political institutions, connectedness, and corporate risk-taking”, Journal of International Business Studies, 44(3), 195215.

Brown, P., 2011, "International Financial Reporting Standards: what are the benefits?"Accounting and Business Research, 41(3), 269-285.

Bushman, R., Chen, Q., Engel, E., \& Smith, A., 2004, "Financial Accounting Information, Organizational Complexity and Corporate Governance Systems”, Journal of Accounting and Economics, 37 (2), 167-201.

Bushman, R. ., \& Piotroski, J. D., 2006, "Financial Reporting Incentives for Conservative Accounting: The Influence of Legal and Political Institutions”, Journal of Accounting and Economics, 42, 107-148.

Carney, M., 2005, "Corporate governance and competitive advantage in familycontrolled firms", Entrepreneurship theory and practice, 29(3), 249-265.

Chaney, P.K., Faccio, M. \& Parsley, D., 2011, "The Quality of Accounting Information in Politically Connected Firms", Journal of Accounting and Economics, 51 (1-2), 58-76.

Chen, S., Chen, X., \& Cheng, Q., 2008, "Do Family Firms Provide More or Less Voluntary Disclosure? ", Journal of Accounting Research, 46(3), 499-536.

Chen, S., Chen, X., \& Cheng, Q., 2014, "Conservatism and Equity Ownership of the Founding Family", European Accounting Review (Special Issue; Accounting and Reporting in Family Firms)", 23 (3), 403-430.

Chen, C. J., Li, Z., Su, X., \& Sun, Z., 2011, "Rent-seeking incentives, corporate political connections, and the control structure of private firms: Chinese evidence”, Journal of Corporate Finance, 17(2), 229-243.

Cheung, Y. L., Rau, P. R., \&Stouraitis, A., 2006, "Tunneling, propping, and expropriation: evidence from connected party transactions in Hong Kong”, Journal of Financial Economics, 82(2), 343-386.

Chi, W., Liu, C., \& Wang, T., 2009, "What Affects Accounting Conservatism: A Corporate Governance Perspective", Journal of Contemporary Accounting and Economics, 5, 47-59.

Claessens, S., Djankov, S., \& Lang, L., 2000, "Separation of Ownership from Control Of East Asian Firms", Journal of Financial Economics, 58, 81-112.

Claessens, S., \& Fan, J. P., 2002, "Corporate Governance in Asia: A Survey", International Review of Finance, 3(2), 71-103.

Crookes, D., \& Thomas, I., 1998, "Problem solving and culture-exploring some stereotypes, “Journal of Management Development, 17(8), 583-591. 
Dietrich, J. R., Muller III, K. A., \& Riedl, E. J., 2007, “Asymmetric timeliness tests of accounting conservatism”, Review of Accounting Studies, 12(1), 95-124.

Elshandidy, T., \& Hassanein, A., 2014, “Do IFRS and board of directors' independence affect accounting conservatism?”, Applied Financial Economics, 24(16), 10911102.

Faccio, M., Masulis, R. W., \& McConnell, J. J., 2006, "Political Connections and Corporate Bailouts", The Journal of Finance, 61(6), 2597-2635.

Fan, J. P., \& Wong, T. J., 2002, "Corporate ownership structure and the informativeness of accounting earnings in East Asia", Journal of Accounting and Economics, 33(3), 401-425.

Filatotchev, I., \& Mickiewicz, T., 2001, "Ownership concentration,'private benefits of control'and debt financing, "Corporate governance and finance in Poland and Russia", 159-176.

Firth, M., He, X., Rui, O. M., \& Xiao, T., 2014, "Paragon or Pariah? The Consequences of Being Conspicuously Rich In China's New Economy", Journal of Corporate Finance, 29, 430-448.

Gassen, J., Fulbier, R. U., \& Sellhorn, T., 2006, "International Differences in Conditional Conservatism: The Role of Unconditional Conservatism and Income Smoothing", European Accounting Review, 15(4).

Givoly, D., Hayn, C. K., \& Natarajan, A., 2007, "Measuring reporting conservatism, "The Accounting Review, 82(1), 65-106.

Guay, W., \& Verrecchia, R., 2006, "Discussion of an economic framework for conservative accounting and Bushman and Piotroski (2006)”, Journal of Accounting and Economics, 42(1), 149-165.

Gul, F. A., 2006, "Auditors' Response to Political Connections and Cronysm in Malaysia", Journal of Accounting Research, 44(5), 931-963.

Gul, F. A., 1999, "Growth opportunities, capital structure and dividend policies in Japan”, Journal of Corporate Finance, 5(2), 141-168.

Haley, G. T., \& Tan, C. T. (1999). East vs. west: strategic marketing management meets the Asian networks. Journal of Business \& Industrial Marketing, 14(2), 91-104.

Hanazaki, M., \& Liu, Q., 2007, “Corporate governance and investment in East Asian firms-empirical analysis of family-controlled firms", Journal of Asian Economics, 18(1), 76-97.

He, X., Rui, O. M., \& Tusheng, X., 2012, "The Price of Being a Billionaire in China: Evidence Based on Hurun Rich List", Available at SSRN 2102998.

Hutchinson, M., \& Gul, F. A., 2004, "Investment Opportunity Set, Corporate Governance Practices and Firm Performance”, Journal of Corporate Finance, 10(4), 595-614.

Jaggi, B., Leung, S., \& Gul, F., 2009, "Family Control, Board Independence and Earnings Management: Evidence Based on Hong Kong Firms", Journal of Accounting Public Policy, 28, 281-300.

Johl, S., Subramaniam, N., \& Mat Zain, M., 2012, "Audit Committee and CEO Ethnicity and Audit Fees: Some Malaysian Evidence", The International Journal of Accounting, 47(3), 302-332.

Johnson, S., \& Mitton, T., 2003, "Cronyism and Capital Controls: Evidence from Malaysia", Journal of Financial Economics, 67 (2), 351-382. 
Joos, P., \& Lang, M., 1994, "The Effects of Accounting Diversity: Evidence from the European Union", Journal of Accounting Research, 32, 141-168.

Kao, G., 1995, "Asian Americans as model minorities? A look at their academic performance", American journal of Education, 103, 121-159.

Khan, M. H., 2003, "The New Political Economy of Corruption", Development Policy in the Twenty-First Century: Beyond the Post-Washington Consensus, London: Routledge 2001, 112-135.

Khan, M., \& Watts, R. L., 2009, "Estimation and empirical properties of a firm-year measure of accounting conservatism", Journal of Accounting and Economics, 48(2-3), 132-150.

Lara, J. M. G., \& Mora, A., 2004, "Balance Sheet versus Earning Conservatism in Europe", European Accounting Review, 13(2), 261-292.

Lara, J. M. G., Osma, B. G., \& Fernando, P., 2009, "Accounting Conservatism and Corporate Governance", Review of Accounting Studies, 14, 161-201.

Lara, J. M. G., Torres, J. A. R., \& Veira, P. J. V., 2008, "Conservatism of Earnings Reported Under International Accounting Standards: A Comparative Study", Spanish Journal of Finance and Accounting, 37(138), 197-210.

Lee, H. S. (Grace), Li, X., \& Sami, H., 2015, "Conditional Conservatism and Audit Fees,Accounting Horizons, 29(1), 83-113.

Lim, M., How, J., \& Verhoeven, P., 2014, "Corporate Ownership, Corporate Governance Reform and Timeliness of Earnings: Malaysian Evidence", Journal of Contemporary Accounting \& Economics, 10(1), 32-45.

Mamman, A., 2002, "Managerial views on government intervention in Malaysia: The relevance of ethnic and employment backgrounds", Asia Pacific Business Review, 9(1), 1-20.

Mohamed Yunos, R., Ismail, Z., \& Smith, M., 2012, "Ethnicity and Accounting Conservatism: Malaysian Evidence", Asian Review of Accounting, 20(1), 34-57.

Neter, J., Wasserman, W. \& Kutner, M.H., 1983. Applied Linear Regression Models. Homewood, Illinois: Richard D. Irwin.

Patatoukas, P. N., \& Thomas, J. K., 2011, "More evidence of bias in the differential timeliness measure of conditional conservatism”, The Accounting Review, 86(5), $1765-1793$.

Pepinsky, T. B., 2008, Capital mobility and coalitional politics: authoritarian regimes and economic adjustment in Southeast Asia, World Politics, 60(03), 438-474.

Pinnuck, M., \& Potter, B. N., 2009, "The quality and conservatism of the accounting earnings of local governments", Journal of Accounting and Public Policy, 28(6), 525-540.

PricewaterhouseCoopers., 2009, "IFRS convergence in 2012: What does it mean for Malaysia?", PwC Alert.

Riahi-Belkoui, A., 2004, "Politically-Connected: Are They Connected To Earnings Opacity", Research in Accounting Regulation, 17, 25-38.

Roychowdhury, S., \& Watts, R. L., 2007, “Asymmetric Timeliness of Earnings, Market-To-Book and Conservatism in Financial Reporting”, Journal of Accounting and Economics, 44(1), 2-31.

Sejati, Y. A., 2009, "Political Connections and Earnings Quality: Evidence from Malaysia", Unpublished Doctoral Dissertation, Oklahoma State University, Stillwater, Oklahama, United States.Studwell, J., 2010, “Asian 
Godfathers: Money and Power in Hong Kong and South East Asia”, Profile Books.

Vichitsarawong, T., Eng, L. L., \& Meek, G. K., 2010, "The Impact of the Asian Financial Crisis on Conservatism and Timeliness of Earnings: Evidence from Hong Kong, Malaysia, Singapore, and Thailand", Journal of International Financial Management and Accounting, 21(1), 32-61.

Vithiatharan, V., \& Gomez E. T., 2014, "Politics, Economic Crises and Corporate Governance Reforms: Regulatory Capture in Malaysia", Journal of Contemporary Asia, 44 (4), 599-615.

Wang, D., 2006, "Founding Family Ownership and Earnings Quality", Journal of Accounting Research, 44 (3), 619-656.

Wan-Hussin, W. N., 2009, "The Impact of Family-Firm Structure and Board Composition on Corporate Transparency: Evidence Based on Segment Disclosures in Malaysia", The International Journal of Accounting, 44, 313-333.

Wan Ismail, W. A., Kamarudin, K. A., Van Zijl, T., \& Dunstan, K., 2013, "Earnings Quality and The Adoption of IFRS-Based Accounting Standards: Evidence From An Emerging Market”,Asian Review of Accounting, 21(1), 53-73.

Watts, R. L., 2003, "Conservatism in Accounting Part I: Explanations and Implications", Accounting Horizons, 17, 207-221.

Weidenbaum, M. L., \& Hughes, S., 1996, "The bamboo network: How expatriate Chinese entrepreneurs are creating a new economic superpower in Asia”, Simon and Schuster.

White, N. J., 2004, "The Beginnings of Crony Capitalism: Business, Politics and Economic Development in Malaysia, c. 1955-70", Modern Asian Studies, 38 (2), 389-417.

Yatim, P., Kent, P., \& Clarkson, P., 2006, "Governance structures, ethnicity, and audit fees of Malaysian listed firms", Managerial Auditing Journal, 21(7), 757-782.

Zeghal, D., Chtourou, S. M., \& Fourati, Y. M., 2012, "The effect of mandatory adoption of IFRS on earnings quality: Evidence from the European Union”, Journal of International Accounting Research, 11(2), 1-25. 
Appendix A

\begin{tabular}{|c|c|c|c|c|c|c|c|}
\hline & Name of Richest Men & $\begin{array}{l}\text { Wealth Worth } \\
\text { (USD) }\end{array}$ & Flagships & & Name of Richest Men & $\begin{array}{l}\text { Wealth Worth } \\
\text { (USD) }\end{array}$ & Flagships \\
\hline 1 & Robert Kuok & 9.0 billion & Diversified & 21 & Chen Lip Keong & 195 million & Gaming \\
\hline 2 & Ananda Krishnan & 7.0 billion & Telecom & 22 & Lee SweeEng & 190 million & Oil Services \\
\hline 3 & Lee Shin Cheng & 3.2 billion & Palm oil & 23 & Jeffrey Cheah & 185 million & Real Estate \\
\hline 4 & Lee Kim Hua & 2.5 billion & Gaming & 24 & Lim Wee Chai & 180 million & $\begin{array}{l}\text { Rubber } \\
\text { Gloves }\end{array}$ \\
\hline 5 & Teh Hong Piow & 2.4 billion & Banking & 25 & Ahmayuddin Ahmad & 175 million & Port \\
\hline 6 & QuekLeng Chan & 2.3 billion & Diversified & 26 & Lee HauHian & 174 million & Diversified \\
\hline 7 & YeohTiong Lay & 1.8 billion & Diversified & 27 & Lau Cho Kun & 165 million & Diversified \\
\hline 8 & $\begin{array}{l}\text { Syed } \\
\text { MokhtarAlBukhary }\end{array}$ & 1.1 billion & Diversified & 28 & Vinod Sekhar & 150 million & Rubber \\
\hline 9 & TiongHiew King & 1.0 billion & Timber & 29 & Liew Kee Sin & 140 million & Real Estate \\
\hline 10 & Vincent Tan & 750 million & Diversified & 30 & Tiah Thee Kian & 135 million & Real Estate \\
\hline 11 & Azman Hashim & 470 million & Finance & 31 & Rozali Ismail & 130 million & Infrastructure \\
\hline 12 & William H.J. Cheng & 390 million & Retail & 32 & Lin Yun Ling & 115 million & Infrastructure \\
\hline 13 & G. Gnanalingam & 260 million & Ports & 33 & Yaw Teck Seng & 113 million & Forestry \\
\hline 14 & Lim KokThay & 225 million & Gaming & 34 & Goh Peng Ooi & 112 million & Software \\
\hline 15 & Anthony Fernandes & 220 million & Airlines & 35 & EleenaAzlan Shah & 110 million & Infrastructure \\
\hline 16 & Mokhzani Mahathir & 215 million & $\begin{array}{c}\text { Oil } \\
\text { Services }\end{array}$ & 36 & David Law Tien Seng & 105 million & Mining \\
\hline 17 & Lee OiHian & 210 million & Diversified & 37 & $\begin{array}{l}\text { Syed Mohd YusofTun Syed } \\
\text { Nasir }\end{array}$ & 100 million & Banking \\
\hline 18 & Chan Fong Ann & 209 million & Palm Oil & 38 & Hamdan Mohamad & 98 million & Infrastructure \\
\hline 19 & Kamarudin Meranun & 205 million & Airlines & 39 & Tan TeongHean & 95 million & Banking \\
\hline 20 & Chong Chook Yew & 200 million & $\begin{array}{c}\text { Real } \\
\text { Estate }\end{array}$ & 40 & Kua Sian Kooi & 90 million & Insurance \\
\hline
\end{tabular}




\section{Appendix B: Alternative Measures of Conditional Conservatism}

The alternative firm-year conditional conservatism measure is based on Ball and Shivakumar's (2005) accruals-based loss recognition measure of conditional conservatism. We modify the Ball and Shivakumar (2005) measure (Equation (A1)) using the methodology adopted by Khan and Watts (2009) to estimate a firm-year measure of conservatism:

$A C C_{i t}=\beta_{0}+\beta_{1 i t} D C_{i t}+\beta_{2 i t} C F O_{i t}+\beta_{3 i t} D C_{i t} * C F O_{i t}+\varepsilon_{i t}$

where $A C C_{i t}$ is the total accruals in year $t$, deflated by the year $t-1$ market value of equity; $C F O_{i t}$ is the cash flow from operations in year $t$, deflated by the year $t-1$ market value of equity and $D C_{i t}$ is a dummy variable that is equal to 1 if $C F O_{i t}$ is negative and is 0 otherwise. The coefficient of the interaction term between $D C$ and $C F O\left(\beta_{3}\right)$ measures the conditional conservatism. If economic losses are recognised in a more timely manner than gains, then $\beta_{3}$ will be greater than 0 .

To estimate the timeliness of good and bad news at the firm-year level, we use Khan and Watts' (2009) specification that the timeliness of good news (AG_SCORE) and the asymmetric timeliness of bad news (AC_SCORE) are linear functions of firm-specific characteristics as follows:

$A G \_S C O R E=b_{1 i t}=\mu_{1 t}+\mu_{2 t} S I Z E_{i t}+\mu_{3 t} M T B_{i t}+\mu_{4 t} L E V_{i t}$

$A C \_S C O R E=b_{3 i t}=\lambda_{1 t}+\lambda_{2 t} S I Z E_{i t}+\lambda_{3 t} M T B_{i t}+\lambda_{4 t} L E V_{i t}$

The accruals-based loss recognition regression (Ball and Shivakumar, 2005) can be re-written as given by Equation (A3) by substituting Equations (A2a) and (A2b) into Equation (A1):

$$
\begin{aligned}
& A C C_{i t}=\beta_{0}+\beta_{1 i t} D C_{i t}+C F O_{i t}\left(\mu_{1 t}+\mu_{2 t} S_{I Z E_{i t}}+\mu_{3 t} M T B_{i t}+\mu_{4 t} L E V_{i t}\right)+\beta_{3 i t} D C_{i t} * C F O_{i t}\left(\lambda_{1 t}+\right. \\
& \left.\lambda_{2 t} S_{Z Z E_{i t}}+\lambda_{3 t} M+B_{i t}+\lambda_{4 t} L E V_{i t}\right)+\left(\delta_{1 t} S I Z E_{i t}+\delta_{2 t} M T B_{i t}+\delta_{3 t} L E V_{i t}+\delta_{4 t} D R_{i t} * S_{Z E}+\right. \\
& \left.\delta_{5 t} D R_{i t} * M T B_{i t}+\delta_{6 t} D R_{i t} * L E V_{i t}\right)+e_{i t}
\end{aligned}
$$

We estimate the annual regression of Equation (A3) and obtain the coefficients of $\lambda_{1 t}, \lambda_{2 t}, \lambda_{3 t}$ and $\lambda_{4 t}$ to estimate AC_SCORE (Equation (A2b)). Conditional conservatism increases with increase in AC_SCORE. 
Table 1: Sample Distribution

\begin{tabular}{lc}
\hline \hline Description & Number of firms \\
\hline $\begin{array}{l}\text { Initial sample } \\
\text { (-) Financial institutions, insurance and real }\end{array}$ & 857 \\
estate companies & $(49)$ \\
(-) PN4 companies, companies that change & $(250)$ \\
financial year end and companies with & \\
missing data & \\
(-) Outliers/missing data & $(118)$ \\
Final Sample (per year) & 440 \\
\hline \hline
\end{tabular}


Table 2: Operational Definitions

\begin{tabular}{|c|c|c|}
\hline Symbol & Definition & Source(s) \\
\hline \multicolumn{3}{|c|}{ Panel A: Main test variables } \\
\hline C_SCORE $E_{i t}$ & $\begin{array}{l}\text { Firm-year conditional conservatism measure } \\
\text { based on Basu (1997) }\end{array}$ & Compustat Global \\
\hline$A C \_S C O R E_{i t}$ & $\begin{array}{l}\text { Firm-year accrual based loss conservatism } \\
\text { measure based on Ball and Shivakumar (2005) }\end{array}$ & Compustat Global \\
\hline$I_{F R S}$ & $\begin{array}{l}\text { An indicator variable that takes the value of } 1 \text { if the } \\
\text { period is post IFRS; } 2007 \text { and } 2008 \text {. }\end{array}$ & - \\
\hline \multicolumn{3}{|c|}{ Panel B: Institutional Variables } \\
\hline$P O L C O N_{i t}$ & $\begin{array}{l}\text { dummy variable; coded as ' } 1 \text { ' if the firms have } \\
\text { political connection and ' } 0 \text { ' otherwise }\end{array}$ & Johnson and Mitton (2003) \\
\hline FAMILY $Y_{i t}$ & $\begin{array}{l}\text { dummy variable; coded as ' } 1 \text { ' if the firms have } \\
\text { family connection and ' } 0 \text { ' otherwise }\end{array}$ & Annual reports \\
\hline$F M \_D I R E C T_{i t}$ & $\begin{array}{l}\text { Measured family control based on the fractional } \\
\text { direct equity ownership held by the controlling } \\
\text { family. }\end{array}$ & Annual reports \\
\hline$F M_{-} I N D I R E C T_{i t}$ & $\begin{array}{l}\text { Measured family control based on the fractional } \\
\text { indirect equity ownership held by the controlling } \\
\text { family. }\end{array}$ & Annual reports \\
\hline RICHEST $_{i t}$ & $\begin{array}{l}\text { dummy variable coded as ' } 1 \text { ' if the one of the } \\
\text { shareholders' of the firm are from richest man and } \\
\text { ' } 0 \text { ' otherwise }\end{array}$ & Annual reports \\
\hline$R C \_D I R E C T_{i t}$ & $\begin{array}{l}\text { Measured richest man control based on the } \\
\text { fractional direct equity ownership held by the } \\
\text { richest man. }\end{array}$ & Annual reports \\
\hline$R C_{-} I N D I R E C T_{i t}$ & $\begin{array}{l}\text { Measured richest man control based on the } \\
\text { fractional indirect equity ownership held by the } \\
\text { richest man. }\end{array}$ & Annual reports \\
\hline$B U M I_{i t}$ & $\begin{array}{l}\text { calculated as percentage of Bumiputras on board } \\
\text { of directors }\end{array}$ & Annual reports \\
\hline \multicolumn{3}{|c|}{ Panel C: Control Variables } \\
\hline$S I Z E_{i t}$ & Natural log of total assets for year $t$ & Compustat Global \\
\hline$M T B_{i t}$ & $\begin{array}{l}\text { Market value of equity divided the book value of } \\
\text { equity for year } t\end{array}$ & Compustat Global \\
\hline$L E V_{i t}$ & Book value of total debt divided by total assets & Compustat Global \\
\hline$B I G 4_{i t}$ & $\begin{array}{l}\text { An indicator variable that takes the value of } 1 \text { if } \\
\text { the firm is audited by the Big } 4 \text { audit firms }\end{array}$ & Annual reports \\
\hline
\end{tabular}


Table 3: Descriptive Statistics $(\mathbf{N}=1760)$

\begin{tabular}{|c|c|c|c|c|c|c|c|c|}
\hline & \multirow{2}{*}{\multicolumn{2}{|c|}{$\begin{array}{l}\text { Pre IFRS } \\
\mathrm{N}=880\end{array}$}} & \multicolumn{2}{|c|}{ Post IFRS } & \multirow{2}{*}{\multicolumn{2}{|c|}{ t-test }} & \multirow{2}{*}{\multicolumn{2}{|c|}{$\begin{array}{l}\text { Mann- } \\
\text { Whitney }\end{array}$}} \\
\hline & & & \multicolumn{2}{|c|}{$\mathrm{N}=880$} & & & & \\
\hline & Mean & Median & Mean & Median & \multicolumn{2}{|l|}{ P-value } & \multicolumn{2}{|l|}{ p-value } \\
\hline \multicolumn{9}{|c|}{ Panel A: Dependent Variable } \\
\hline C_SCORE $E_{i t}$ & -6.783 & -7.430 & 6.866 & -23.768 & 0.556 & & 0.079 & * \\
\hline$A C \_S C O R E_{i t}$ & 0.023 & 0.000 & 0.028 & 0.000 & 0.848 & & 0.812 & \\
\hline \multicolumn{9}{|c|}{ Panel B: Institutional Variables } \\
\hline$P O L C O N_{i t}$ & 0.386 & 0.000 & 0.386 & 0.000 & - & & & \\
\hline FAMILY $Y_{i t}$ & 0.600 & 1.000 & 0.600 & 1.000 & - & & & \\
\hline$F M \_D I R E C T_{i t}$ & 5.453 & 0.105 & 6.657 & 0.177 & 0.915 & & 0.997 & \\
\hline$F M_{-} I N D I R E C T_{i t}$ & 16.605 & 0.000 & 16.553 & 0.000 & 0.814 & & 0.972 & \\
\hline RICHEST $_{i t}$ & 0.100 & 0.000 & 0.100 & 0.000 & - & & & \\
\hline$R C \_D I R E C T_{i t}$ & 0.717 & 0.000 & 0.866 & 0.000 & 0.272 & & 0.967 & \\
\hline$R C \_I N D I R E C T_{i t}$ & 3.898 & 0.000 & 3.565 & 0.000 & 0.406 & & 0.290 & \\
\hline$B U M I_{i t}$ & 37.290 & 33.330 & 35.150 & 28.570 & 0.510 & & 0.359 & \\
\hline \multicolumn{9}{|c|}{ Panel C: Control Variables } \\
\hline$S I Z E_{i t}$ & 19.802 & 19.748 & 19.693 & 19.573 & 0.018 & $* *$ & 0.015 & $* *$ \\
\hline$M T B_{i t}$ & 0.703 & 0.490 & 1.264 & 0.874 & 0.488 & & 0.000 & $* * *$ \\
\hline$L E V_{i t}$ & 0.419 & 0.394 & 0.420 & 0.411 & 0.362 & & 0.394 & \\
\hline$B I G 4_{i t}$ & 0.577 & 0.000 & 0.642 & 0.000 & $\begin{array}{r}\text { (Chi-Square) } \\
(0.383)\end{array}$ & & & \\
\hline
\end{tabular}

C_SCORE is the firm-year conditional conservatism measure based on Basu (1997). AC_SCORE is the firm-year conditional conservatism measure based on accrual-based loss recognition model of Ball and Shivakumar (2005). IFRS is an indicator variable that takes the value of 1 if the period is 2007-2008. POLCON takes the value of 1 if the firm is politically-connected based on Johnson and Mitton (2003). FAMILY takes the value of 1 if the firms has family connections, zero otherwise. FM_DIRECT and FM_INDIRECT are direct and indirect ownership held by controlling family respectively. RICHEST is a dummy variable that takes the value of 1 if one of the shareholders are from the richest man, zero otherwise. RC_DIRECT and RC_INDIRECT are direct and indirect shareholdings held by richest man in the firms respectively. BUMI is calculated as percentage of Bumiputras directors on board. SIZE is natural log transformation of total assets for year t. MTB is market to book ratio. LEV is book value of total debt divided by total assets. BIG4 is an indicator variable that takes the value of 1 if the firm is audited by the Big 4 audit firms. $\chi^{2}$ results are in parenthesis. *, ** and ${ }^{* * *}$ represent 10,5 and 1 per cent significant levels respectively. 
Table 4: Correlations

\begin{tabular}{|c|c|c|c|c|c|c|c|c|c|c|c|c|c|c|c|}
\hline & & 1 & & 2 & & 3 & & 4 & & 5 & & 6 & & 7 & \\
\hline C_SCORE $E_{i t}$ & 1 & & & 0.127 & $* * *$ & -0.024 & & -0.064 & & 0.075 & $* * *$ & 0.088 & $* * *$ & 0.065 & $* * *$ \\
\hline$A C \_S C O R E_{i t}$ & 2 & 0.010 & & & & 0.010 & & -0.020 & & 0.061 & $* * *$ & 0.084 & $* * *$ & 0.023 & \\
\hline$I F R S_{i t}$ & 3 & 0.031 & & 0.005 & & & & -0.024 & & 0.013 & & 0.031 & & 0.013 & \\
\hline$P O L C O N_{i t}$ & 4 & -0.001 & & -0.045 & $*$ & -0.024 & & & & -0.044 & $*$ & -0.046 & $*$ & -0.065 & $* * *$ \\
\hline FAMILY $Y_{i t}$ & 5 & 0.016 & & 0.023 & & 0.013 & & -0.044 & $*$ & & & 0.788 & $* * *$ & 0.720 & $* * *$ \\
\hline$F M \_D I R E C T_{i t}$ & 6 & 0.016 & & 0.047 & $*$ & 0.049 & $* *$ & -0.012 & & 0.419 & $* * *$ & & & 0.433 & $* * *$ \\
\hline$F M \_I N D I R E C T_{i t}$ & 7 & 0.019 & & 0.001 & & -0.001 & & -0.076 & $* * *$ & 0.612 & $* * *$ & -0.131 & $* * *$ & & \\
\hline RICHEST $_{i t}$ & 8 & -0.050 & $* *$ & 0.000 & & -0.020 & & 0.092 & $* * *$ & -0.020 & & -0.036 & & 0.047 & $*$ \\
\hline$R C \_D I R E C T_{i t}$ & 9 & -0.014 & & -0.009 & & 0.013 & & 0.037 & & 0.036 & & 0.149 & $* * *$ & 0.003 & \\
\hline$R C \_I N D I R E C T_{i t}$ & 10 & -0.038 & & 0.010 & & -0.012 & & 0.050 & $* *$ & -0.002 & & -0.104 & $* * *$ & 0.110 & $* * *$ \\
\hline$B U M I_{i t}$ & 11 & -0.018 & & 0.037 & & 0.038 & & -0.204 & $* * *$ & 0.279 & $* * *$ & 0.179 & $* * *$ & 0.196 & $* * *$ \\
\hline$S I Z E_{i t}$ & 12 & -0.009 & & -0.024 & & -0.055 & $* *$ & 0.202 & $* * *$ & -0.094 & $* * *$ & -0.146 & $* * *$ & -0.012 & \\
\hline$M T B_{i t}$ & 13 & -0.023 & & -0.011 & & 0.224 & $* * *$ & -0.025 & & -0.075 & $* * *$ & 0.036 & & -0.076 & $* * *$ \\
\hline$L E V_{i t}$ & 14 & -0.037 & & -0.139 & $* * *$ & 0.003 & & 0.080 & $* * *$ & -0.028 & & 0.034 & & -0.118 & $* * *$ \\
\hline$B I G 4_{i t}$ & 15 & 0.046 & $*$ & -0.003 & & -0.066 & $* * *$ & 0.072 & $* * *$ & -0.050 & $* *$ & -0.053 & $* *$ & -0.022 & \\
\hline
\end{tabular}

C_SCORE it $_{\text {C }}$ is the firm-year conditional conservatism measure based on Basu (1997). AC_SCORE is the firm-year conditional conservatism measure based on accrual-based loss recognition model of Ball and Shivakumar (2005). IFRS is an indicator variable that takes the value of 1 if the period is 2007-2008. POLCON takes the value of 1 if the firm is politically-connected based on Johnson and Mitton (2003). FAMILY takes the value of 1 if the firms has family connections, zero otherwise. FM_DIRECT and FM_INDIRECT are direct and indirect ownership held by controlling family respectively. RICHEST is a dummy variable that takes the value of 1 if one of the shareholders are from the richest man, zero otherwise. RC_DIRECT and RC_INDIRECT are direct and indirect shareholdings held by richest man in the firms respectively. BUMI is calculated as percentage of Bumiputras directors on board. SIZE is natural log transformation of total assets for year t. MTB is market to book ratio. LEV is book value of total debt divided by total assets. BIG4 is an indicator variable that takes the value of 1 if the firm is audited by the Big 4 audit firms. Spearman-rank correlations are italicised. ***, **, * represents 1, 5 and 10 per cent significant levels respectively. 
Table 4 Correlations (continued)

\begin{tabular}{|c|c|c|c|c|c|c|c|c|c|c|c|c|c|c|c|c|c|}
\hline & & 8 & & 9 & & 10 & & 11 & & 12 & & 13 & & 14 & & 15 & \\
\hline C_SCORE $E_{i t}$ & 1 & -0.090 & $* * *$ & -0.037 & & -0.100 & $* * *$ & 0.062 & $* *$ & -0.138 & $* * *$ & -0.026 & & -0.148 & $* * *$ & -0.052 & $* *$ \\
\hline$A C \_S C O R E_{i t}$ & 2 & -0.035 & & -0.058 & $* *$ & -0.035 & & 0.008 & & 0.032 & & 0.006 & & 0.080 & $* * *$ & -0.041 & $*$ \\
\hline$I F R S_{i t}$ & 3 & -0.020 & & -0.037 & & -0.013 & & 0.044 & $*$ & -0.059 & $* *$ & 0.330 & $* * *$ & 0.028 & & -0.066 & $* * *$ \\
\hline$P O L C O N_{i t}$ & 4 & 0.092 & $* * *$ & 0.057 & $* *$ & 0.098 & $* * *$ & -0.214 & $* * *$ & 0.200 & $* * *$ & -0.063 & $* *$ & 0.070 & $* * *$ & 0.072 & $* * *$ \\
\hline$F A M I L Y_{i t}$ & 5 & -0.020 & & 0.045 & $*$ & -0.024 & & 0.274 & $* * *$ & -0.091 & $* * *$ & -0.050 & $* *$ & -0.031 & & -0.050 & $* *$ \\
\hline$F M_{-} D I R E C T_{i t}$ & 6 & -0.063 & $* * *$ & 0.067 & $* * *$ & -0.087 & $* * *$ & 0.286 & $* * *$ & -0.145 & $* * *$ & 0.012 & & 0.017 & & -0.050 & $* *$ \\
\hline$F M \_I N D I R E C T_{i t}$ & 7 & 0.017 & & 0.062 & $* *$ & 0.031 & & 0.243 & $* * *$ & -0.039 & & -0.053 & $* *$ & -0.106 & $* * *$ & -0.021 & \\
\hline RICHEST $_{i t}$ & 8 & & & 0.697 & $* * *$ & 0.919 & $* * *$ & -0.041 & $*$ & 0.350 & $* * *$ & -0.090 & $* * *$ & -0.023 & & 0.041 & $*$ \\
\hline$R C \_D I R E C T_{i t}$ & 9 & 0.436 & $* * *$ & & & 0.541 & $* * *$ & -0.027 & & 0.239 & $* * *$ & -0.042 & $*$ & -0.025 & & 0.035 & \\
\hline$R C \_I N D I R E C T_{i t}$ & 10 & 0.801 & $* * *$ & 0.075 & $* * *$ & & & -0.039 & & 0.311 & $* * *$ & -0.080 & $* *$ & -0.002 & & 0.048 & $* *$ \\
\hline$B U M I_{i t}$ & 11 & -0.010 & & 0.029 & & 0.011 & & & & -0.201 & $* * *$ & 0.068 & $* * *$ & -0.124 & $* * *$ & 0.014 & \\
\hline$S I Z E_{i t}$ & 12 & 0.378 & $* * *$ & 0.163 & $* * *$ & 0.302 & $* * *$ & -0.183 & $* * *$ & & & -0.269 & $* * *$ & 0.193 & $* * *$ & 0.089 & $* * *$ \\
\hline$M T B_{i t}$ & 13 & -0.038 & & -0.019 & & -0.040 & $*$ & 0.004 & & -0.157 & $* * *$ & & & 0.162 & $* * *$ & -0.101 & $* * *$ \\
\hline$L E V_{i t}$ & 14 & -0.016 & & -0.020 & & -0.017 & & -0.120 & $* * *$ & 0.156 & $* * *$ & 0.057 & $* *$ & & & -0.043 & $*$ \\
\hline$B I G 4_{i t}$ & 15 & 0.041 & $*$ & -0.029 & & 0.056 & $* *$ & 0.013 & & 0.088 & $* * *$ & -0.059 & $* *$ & -0.062 & $* *$ & & \\
\hline
\end{tabular}

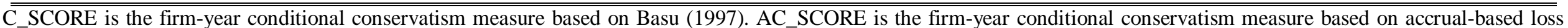

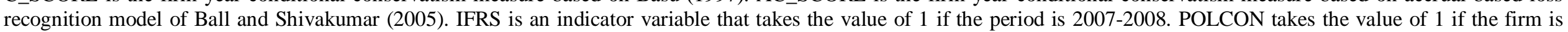

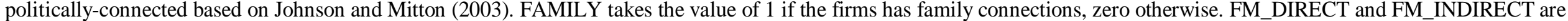

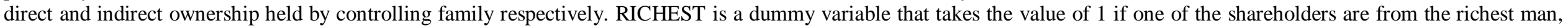

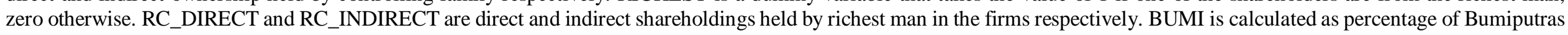

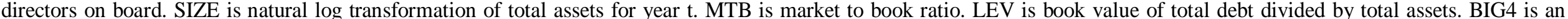

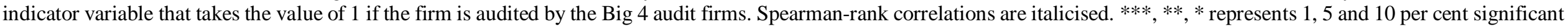
levels respectively. 
Table 5: Main regression (IFRS)

$$
\begin{aligned}
& \text { C_SCORE }_{i t}=\beta_{0}+\beta_{1} \text { IFRS }_{i t}+\beta_{2} \text { SIZE }_{i t}+\beta_{3} \text { MTB }_{i t}+\beta_{4} L E V_{i t}+\beta_{5} \text { BIG }_{i t} \\
& +\sum \beta_{j} \text { PERIOD }_{i t}+\sum \beta_{k} \text { INDUSTRIES }_{i t}+\varepsilon_{i t}
\end{aligned}
$$

\begin{tabular}{|c|c|c|c|c|c|}
\hline \multirow[t]{2}{*}{ DV } & Expected & C SCORE $_{i t}$ & \multicolumn{3}{|c|}{ AC_SCORE $E_{i t}$} \\
\hline & Direction & 1 & & 2 & \\
\hline \multirow[t]{2}{*}{ INTERCEPT $_{i t}$} & $?$ & 152.675 & & -0.001 & \\
\hline & & 2.550 & $* *$ & -0.239 & \\
\hline \multirow[t]{2}{*}{$I F R S_{i t}$} & $?$ & 10.842 & & 0.001 & \\
\hline & & 2.396 & $* *$ & 2.358 & $* *$ \\
\hline \multirow[t]{2}{*}{$S I Z E_{i t}$} & - & -6.975 & & 0.000 & \\
\hline & & -2.430 & $* *$ & 0.322 & \\
\hline \multirow[t]{2}{*}{$M T B_{i t}$} & + & -0.034 & & -0.001 & \\
\hline & & -0.180 & & -0.500 & \\
\hline \multirow[t]{2}{*}{$L E V_{i t}$} & + & -32.155 & & -0.001 & \\
\hline & & -2.996 & $* * *$ & -1.431 & * \\
\hline \multirow[t]{2}{*}{$B I G 4_{i t}$} & + & 9.376 & & 0.000 & \\
\hline & & 1.707 & $*$ & 1.118 & \\
\hline Period fixed & $?$ & Yes & & Yes & \\
\hline Industry fixed & ? & Yes & & Yes & \\
\hline Adjusted $R^{2}$ & & 0.021 & & 0.007 & \\
\hline F-statistic & & 3.501 & $* * *$ & 1.534 & $*$ \\
\hline VIF & & 2.878 & & 3.145 & \\
\hline
\end{tabular}

C_SCORE is the firm-year conditional conservatism measure based on Basu (1997). AC_SCORE is the firm-year conditional conservatism measure based on accrualbased loss recognition model of Ball and Shivakumar (2005). IFRS is an indicator variable that takes the value of 1 if the period is 2007-2008. SIZE is natural log transformation of total assets for year t. MTB is market to book ratio. LEV is book value of total debt divided by total assets. BIG4 is an indicator variable that takes the value of 1 if the firm is audited by the Big 4 audit firms. *, ** and *** represent 10 , 5 and 1 per cent significant levels respectively. 
Table 6: Composition

C_SCORE $i t$ or AC_SCORE $i t=\beta_{0}+\beta_{1} I_{\text {IFRS }}+\beta_{2 t}$ POLCON $_{i t}+\beta_{3}$ BUMI $_{i t}+\beta_{4}$ FAMILY $_{i t}+\beta_{5}$ RICHEST $_{i t}+$ $\beta_{6}$ POLCON $^{*} I F R S_{i t}+\beta_{7}$ BUMI*IFRS $_{i t}+\beta_{8}$ FAMILY*IFRS $_{i t}+\beta_{9}$ RICHEST $^{*} I F R S_{i t}+\beta_{10}$ SIZE $_{i t}+\beta_{11}$ MTB $_{i t}+$ $\beta_{12} L E V_{i t}+\beta_{13} B_{I G 4_{i t}}+\sum \beta_{j}$ PERIOD $_{i t}+\sum \beta_{k}$ INDUSTRIES $_{i t}+\varepsilon_{i t}$

\begin{tabular}{|c|c|c|c|c|c|}
\hline & Expected & $C_{-} S C O R E_{i t}$ & & $A C \_S C O R E_{i t}$ & \\
\hline & Direction & 1 & & 2 & \\
\hline \multirow[t]{2}{*}{ INTERCEPT } & $?$ & 77.333 & & -0.050 & \\
\hline & & 1.184 & & -1.552 & \\
\hline \multirow[t]{2}{*}{$I F R S_{i t}$} & $?$ & 29.530 & & 0.001 & \\
\hline & & 2.215 & $* *$ & 0.038 & \\
\hline \multirow[t]{2}{*}{$P O L C O N_{i t}$} & - & -7.010 & & -0.001 & \\
\hline & & -0.952 & & -0.029 & \\
\hline \multirow[t]{2}{*}{$B U M I_{i t}$} & - & -0.192 & & -0.001 & \\
\hline & & -1.396 & & -0.820 & \\
\hline \multirow[t]{2}{*}{$F A M I L Y_{i t}$} & - & 8.026 & & 0.011 & \\
\hline & & 1.054 & & 3.117 & $* * *$ \\
\hline \multirow[t]{2}{*}{ RICHEST $_{i t}$} & - & -5.458 & & 0.006 & \\
\hline & & -0.468 & & 1.134 & \\
\hline \multirow[t]{2}{*}{$P O L C O N_{i t} * I F R S_{i t}$} & + & 5.440 & & 0.002 & \\
\hline & & 0.579 & & 0.517 & \\
\hline \multirow[t]{2}{*}{$B U M I_{i t} * I F R S_{i t}$} & + & 0.383 & & 0.000 & \\
\hline & & 2.171 & $* *$ & 0.268 & \\
\hline \multirow[t]{2}{*}{ FAMIL $_{i t}{ }^{*} I F R S_{i t}$} & + & 10.648 & & -0.008 & \\
\hline & & 1.100 & & -1.746 & $*$ \\
\hline \multirow[t]{2}{*}{ RICHEST $_{i t}{ }^{*} I F R S_{i t}$} & + & -28.021 & & -0.015 & \\
\hline & & -1.895 & $*$ & -1.997 & $* *$ \\
\hline \multirow[t]{2}{*}{$S I Z E_{i t}$} & - & -3.924 & & 0.003 & \\
\hline & & -1.255 & & 2.108 & ** \\
\hline \multirow[t]{2}{*}{$M T B_{i t}$} & + & 0.035 & & -0.001 & \\
\hline & & 0.182 & & -0.273 & \\
\hline \multirow[t]{2}{*}{$L E V_{i t}$} & + & -32.975 & & -0.005 & \\
\hline & & -3.061 & $* * *$ & -0.980 & \\
\hline \multirow[t]{2}{*}{$B I G 4_{i t}$} & + & 8.654 & & 0.001 & \\
\hline & & 1.578 & & 0.039 & \\
\hline Period fixed & ? & Yes & & Yes & \\
\hline Industry fixed & ? & Yes & & Yes & \\
\hline Adjusted $R^{2}$ & & 0.030 & & 0.001 & \\
\hline F-statistic & & 3.354 & $* * *$ & 1.041 & \\
\hline VIF & & 3.363 & & 8.451 & \\
\hline
\end{tabular}


C_SCORE is the firm-year conditional conservatism measure based on Basu (1997). AC_SCORE is the firm-year conditional conservatism measure based on accrual-based loss recognition model of Ball and Shivakumar (2005). IFRS is an indicator variable that takes the value of 1 if the period is 2007-2008. POLCON takes the value of 1 if the firm is politically-connected based on Johnson and Mitton (2003). FAMILY takes the value of 1 if the firms has family connections, zero otherwise. RICHEST is a dummy variable that takes the value of 1 if one of the shareholders are from the richest man, zero otherwise. BUMI is calculated as percentage of Bumiputras directors on board. SIZE is natural log transformation of total assets for year t. MTB is market to book ratio. LEV is book value of total debt divided by total assets. BIG4 is an indicator variable that takes the value of 1 if the firm is audited by the Big 4 audit firms. *, ** and $* * *$ represent 10,5 and 1 per cent significant levels respectively. 


\section{Table 7: Direct Ownership}

C_SCORE $i t$ or AC_SCORE $E_{i t}=\beta_{0}+\beta_{1} I_{F R S_{i t}}+\beta_{2} P_{\text {POLCON }}$ it $+\beta_{3}$ BUMI $_{i t}+\beta_{4}$ FM_DIRECT $_{i t}+$ $\beta_{5} R_{\text {RC_DIRECT }}+\beta_{6}$ POLCON $^{*}$ IFRS $_{\text {it }}+\beta_{7}$ BUMI*IFRS $_{\text {it }}+\beta_{8}$ FM_DIRECT $^{*} I F R S_{i t}+$ $\beta_{9} R C \_D I R E C T^{*} I F R S_{i t}+\beta_{10}$ SIZE $_{i t}+\beta_{11}$ MTB $_{i t}+\beta_{12} L E V_{i t}+\beta_{13} B_{I G} 4_{i t}+\sum \beta_{j} P_{E R I O D}{ }_{i t}+\sum \beta_{k} I_{\text {INDUSTRIES }}$ $+\varepsilon_{i t}$

\begin{tabular}{|c|c|c|c|c|c|}
\hline & Expected & $C_{-} S C O R E_{i t}$ & & $A C \_S C O R E_{i t}$ & \\
\hline & Direction & 1 & & 2 & \\
\hline \multirow[t]{2}{*}{ INTERCEPT $_{\text {it }}$} & $?$ & 171.380 & & -0.003 & \\
\hline & & 2.691 & $* * *$ & -0.708 & \\
\hline \multirow[t]{2}{*}{$I F R S_{i t}$} & $?$ & 35.871 & & 0.002 & \\
\hline & & 2.730 & $* * *$ & 1.767 & $*$ \\
\hline \multirow[t]{2}{*}{$P O L C O N_{i t}$} & - & -7.371 & & -0.001 & \\
\hline & & -1.006 & & -0.878 & \\
\hline \multirow[t]{2}{*}{$B U M I_{i t}$} & - & -0.202 & & -0.000 & \\
\hline & & -1.506 & & -1.503 & \\
\hline \multirow[t]{2}{*}{$F M \_D I R E C T_{i t}$} & - & 0.364 & & -0.001 & \\
\hline & & 1.188 & & -2.687 & $* * *$ \\
\hline \multirow[t]{2}{*}{$R C \_D I R E C T_{i t}$} & - & -0.214 & & 0.000 & \\
\hline & & -0.262 & & 0.266 & \\
\hline \multirow[t]{2}{*}{$P O L C O N_{i t} * I F R S_{i t}$} & + & 5.104 & & 0.000 & \\
\hline & & 0.541 & & 0.579 & \\
\hline \multirow[t]{2}{*}{$B U M I_{i t}{ }^{*} I F R S_{i t}$} & + & 0.350 & & 0.000 & \\
\hline & & 2.022 & $* *$ & 1.854 & $*$ \\
\hline \multirow[t]{2}{*}{$F M_{-} D I R E C T_{i t}{ }^{*} I F R S_{i t}$} & + & 0.035 & & 0.000 & \\
\hline & & 0.093 & & 2.020 & $* *$ \\
\hline \multirow[t]{2}{*}{$R C \_D I R E C T_{i t}{ }^{*} I F R S_{i t}$} & + & -0.300 & & -0.001 & \\
\hline & & -0.318 & & -0.142 & \\
\hline \multirow[t]{2}{*}{$S I Z E_{i t}$} & - & -8.120 & & 0.000 & \\
\hline & & -2.687 & $* * *$ & 0.782 & \\
\hline \multirow[t]{2}{*}{$M T B_{i t}$} & + & -8.265 & & -0.001 & \\
\hline & & -3.943 & $* * *$ & -0.788 & \\
\hline \multirow[t]{2}{*}{$L E V_{i t}$} & + & -29.308 & & -0.001 & \\
\hline & & -2.719 & $* * *$ & -1.771 & $*$ \\
\hline \multirow[t]{2}{*}{$B I G 4_{i t}$} & + & 8.850 & & 0.000 & \\
\hline & & 1.611 & & 0.738 & \\
\hline Period fixed & $?$ & Yes & & Yes & \\
\hline Industry fixed & $?$ & Yes & & Yes & \\
\hline Adjusted $R^{2}$ & & 0.032 & & 0.016 & \\
\hline F-statistic & & 3.460 & $* * *$ & 1.730 & $* * *$ \\
\hline$V I F$ & & 3.362 & & 4.405 & \\
\hline
\end{tabular}


C_SCORE is the firm-year conditional conservatism measure based on Basu (1997). AC_SCORE is the firm-year conditional conservatism measure based on accrual-based loss recognition model of Ball and Shivakumar (2005). IFRS is an indicator variable that takes the value of 1 if the period is 2007-2008. POLCON takes the value of 1 if the firm is politically-connected based on Johnson and Mitton (2003). FM_DIRECT is direct ownership held by controlling family. RC_DIRECT is direct shareholdings held by richest man in the firms. BUMI is calculated as percentage of Bumiputras directors on board. SIZE is natural log transformation of total assets for year t. MTB is market to book ratio. LEV is book value of total debt divided by total assets. BIG4 is an indicator variable that takes the value of 1 if the firm is audited by the Big 4 audit firms. ${ }^{*}, * *$ and $* * *$ represent 10,5 and 1 per cent significant levels respectively. 


\section{Table 8: Indirect Ownership}

$C_{-} S C O R E_{i t}$ or AC_SCORE $i t=\beta_{0}+\beta_{1}$ IFRS $_{i t}+\beta_{2}$ POLCON $_{i t}+\beta_{3}$ BUMI $_{i t}+\beta_{4}$ FM_INDIRECT $_{i t}+$ $\beta_{5} R C_{-} I N D I R E C T_{i t}+\beta_{6}$ POLCON*IFRS $_{i t}+\beta_{7}$ BUMI*IFRS $_{i t}+\beta_{8}$ FM_INDIRECT*IFRS $_{i t}+$ $\beta_{9} R C \_I N D I R E C T * I_{F R S}+\beta_{10}$ SIZE $_{i t}+\beta_{11}$ MTB $_{i t}+\beta_{12} L E V_{i t}+\beta_{13}$ BIG4 $_{i t}+\sum \beta_{j}$ PERIOD $_{i t}+\sum \beta_{k}$ INDUSTRIES $_{i t}$ $+\varepsilon_{i t}$

\begin{tabular}{|c|c|c|c|c|c|}
\hline & Expected & $C_{-} S C O R E_{i t}$ & & AC_SCORE $E_{i t}$ & \\
\hline & Direction & 1 & & 2 & \\
\hline \multirow[t]{2}{*}{ INTERCEPT $_{i t}$} & $?$ & 167.291 & & -0.007 & \\
\hline & & 2.536 & $* *$ & -1.619 & \\
\hline \multirow[t]{2}{*}{$I_{F R S}$} & ? & 35.603 & & 0.003 & \\
\hline & & 2.678 & $* * *$ & 2.206 & $* * *$ \\
\hline \multirow[t]{2}{*}{$P O L C O N_{i t}$} & - & -8.229 & & -0.001 & \\
\hline & & -1.106 & & -1.136 & \\
\hline \multirow[t]{2}{*}{$B U M I_{i t}$} & - & -0.250 & & -0.000 & \\
\hline & & -1.836 & $*$ & -2.090 & $* *$ \\
\hline \multirow[t]{2}{*}{$F M_{-} I N D I R E C T_{i t}$} & - & -0.083 & & 0.000 & \\
\hline & & -0.491 & & 0.938 & \\
\hline \multirow[t]{2}{*}{$R C \_I N D I R E C T_{i t}$} & - & 0.100 & & 0.000 & \\
\hline & & 0.367 & & 1.005 & \\
\hline \multirow[t]{2}{*}{ POLCON $_{\text {it }} * I F R S_{i t}$} & + & 6.423 & & 0.000 & \\
\hline & & 0.675 & & 0.735 & \\
\hline \multirow[t]{2}{*}{$B U M I_{i t} * I F R S_{i t}$} & + & 0.412 & & 0.000 & \\
\hline & & 2.365 & $* *$ & 1.772 & * \\
\hline \multirow[t]{2}{*}{$F M_{-} I N D I R E C T_{i t}{ }^{*} I F R S_{i t}$} & + & 0.388 & & -0.001 & \\
\hline & & 1.780 & $*$ & -1.136 & \\
\hline \multirow[t]{2}{*}{$R C \_I N D I R E C T_{i t}{ }^{*} I F R S_{i t}$} & + & -0.692 & & -0.001 & \\
\hline & & -2.025 & $* *$ & -1.155 & \\
\hline \multirow[t]{2}{*}{$S I Z E_{i t}$} & - & -7.974 & & 0.000 & \\
\hline & & -2.569 & $* * *$ & 1.240 & \\
\hline \multirow[t]{2}{*}{$M T B_{i t}$} & + & -8.094 & & -0.001 & \\
\hline & & -3.859 & $* * *$ & -0.589 & \\
\hline \multirow[t]{2}{*}{$L E V_{i t}$} & + & -28.414 & & -0.001 & \\
\hline & & -2.618 & $* * *$ & -1.523 & \\
\hline \multirow[t]{2}{*}{$B I G 4_{i t}$} & + & 9.660 & & 0.000 & \\
\hline & & 1.754 & $*$ & 0.273 & \\
\hline Period fixed & $?$ & Yes & & Yes & \\
\hline Industry fixed & $?$ & Yes & & Yes & \\
\hline Adjusted $R^{2}$ & & 0.036 & & 0.014 & \\
\hline F-statistic & & 3.739 & $* * *$ & 0.039 & \\
\hline$V I F$ & & 3.377 & & 5.356 & \\
\hline
\end{tabular}


C_SCORE is the firm-year conditional conservatism measure based on Basu (1997). AC_SCORE is the firm-year conditional conservatism measure based on accrual-based loss recognition model of Ball and Shivakumar (2005). IFRS is an indicator variable that takes the value of 1 if the period is 2007-2008. POLCON takes the value of 1 if the firm is politically-connected based on Johnson and Mitton (2003). FM_INDIRECT is indirect ownership held by controlling family. RC_INDIRECT is indirect shareholdings held by richest man in the firms. BUMI is calculated as percentage of Bumiputras directors on board. SIZE is natural log transformation of total assets for year t. MTB is market to book ratio. LEV is book value of total debt divided by total assets. BIG4 is an indicator variable that takes the value of 1 if the firm is audited by the Big 4 audit firms. *, ** and ${ }^{* * *}$ represent 10,5 and 1 per cent significant levels respectively. 